\title{
GSH/ROS Dual-Responsive Supramolecular Nanoparticles Based on Pillar[6]arene and Betulinic Acid Prodrug for Chemo-Chemodynamic Combination Therapy
}

\author{
Peng Zhu ${ }^{1,2} \mathbb{D}$, Weidan Luo ${ }^{1}$, Jianqiang Qian ${ }^{2}$, Chi Meng ${ }^{2}$, Wenpei Shan ${ }^{2}$, Zhongyuan Xu ${ }^{2}$, Wei Zhang ${ }^{1}$, \\ Xin Liu ${ }^{2, *}$ and Yong Ling ${ }^{2, *}$ \\ 1 State Key Laboratory of Quality Research in Chinese Medicine, Macau Institute for Applied Research in \\ Medicine and Health, Macau University of Science and Technology, Taipa, Macau 999078, China; \\ zp1216834231@gmail.com (P.Z.); luoweidan111@163.com (W.L.); wzhang@must.edu.mo (W.Z.) \\ 2 School of Pharmacy and Jiangsu Province Key Laboratory for Inflammation and Molecular Drug Target, \\ Nantong University, Nantong 226001, China; qiq1273752353@163.com (J.Q.); jsxzmc123456@163.com (C.M.); \\ swp1902@163.com (W.S.); xzy424052148@163.com (Z.X.) \\ * Correspondence: xinliunju@foxmail.com (X.L.); Lyyy111@sina.com (Y.L.)
}

Citation: Zhu, P.; Luo, W.; Qian, J.; Meng, C.; Shan, W.; Xu, Z.; Zhang, W.; Liu, X.; Ling, Y. GSH/ROS Dual-Responsive Supramolecular Nanoparticles Based on Pillar[6]arene and Betulinic Acid Prodrug for Chemo-Chemodynamic Combination Therapy. Molecules 2021, 26, 5900. https://doi.org/10.3390/ molecules 26195900

Academic Editor:

Constantinos Tsitsilianis

Received: 15 September 2021

Accepted: 27 September 2021

Published: 29 September 2021

Publisher's Note: MDPI stays neutral with regard to jurisdictional claims in published maps and institutional affiliations.

Copyright: (c) 2021 by the authors. Licensee MDPI, Basel, Switzerland. This article is an open access article distributed under the terms and conditions of the Creative Commons Attribution (CC BY) license (https:/ / creativecommons.org/licenses/by/ $4.0 /)$.

\begin{abstract}
Chemodynamic therapy (CDT) based on intracellular Fenton reactions is attracting increasing interest in cancer treatment. A simple and novel method to regulate the tumor microenvironment for improved CDT with satisfactory effectiveness is urgently needed. Therefore, glutathione (GSH)/ROS (reactive oxygen species) dual-responsive supramolecular nanoparticles (GOx@BNPs) for chemo-chemodynamic combination therapy were constructed via host-guest complexation between water-soluble pillar[6]arene and the ferrocene-modified natural anticancer product betulinic acid (BA) prodrug, followed by encapsulation of glucose oxidase (GOx) in the nanoparticles. The novel supramolecular nanoparticles could be activated by the overexpressed GSH and ROS in the tumor microenvironment (TME), not only accelerating the dissociation of nanoparticles-and, thus, improving the BA recovery and release capability in tumors-but also showing the high-efficiency conversion of glucose into hydroxyl radicals $(\cdot \mathrm{OH})$ in succession through intracellular Fenton reactions. Investigation of antitumor activity and mechanisms revealed that the dramatic suppression of cancer cell growth induced by GOx@BNPs was derived from the elevation of ROS, decrease in ATP and mitochondrial transmembrane potential (MTP) and, finally, cell apoptosis. This work presents a novel method for the regulation of the tumor microenvironment for improved CDT, and the preparation of novel GSH/ROS dual-responsive supramolecular nanoparticles, which could exert significant cytotoxicity against cancer cells through the synergistic interaction of chemodynamic therapy, starvation therapy, and chemotherapy (CDT/ST/CT).
\end{abstract}

Keywords: chemodynamic therapy (CDT); tumor microenvironment (TME); dual-responsive; betulinic acid (BA); pillar[6]arene; glucose oxidase (GOx)

\section{Introduction}

Cancer is a devastating disease with an ever-increasing mortality rate every year, and represents one of the biggest challenges to human health all over the world $[1,2]$. Chemotherapeutic drugs are still the most important way to treat cancer [3]. Naturalproduct-based chemotherapeutic drugs remain the most effective way to treat cancer [4]. Of the 175 small molecules approved for cancer treatment from the 1940s to the end of 2014, $75 \%$ are of non-synthetic origin, with $49 \%$ being either natural products or directly derived therefrom [5]. Betulinic acid (BA) is a natural lupane-type pentacyclic triterpenoid saponin usually isolated from birch tree bark, and is also present in many other botanical sources, demonstrating multiple bioactivities-particularly an antitumor effect via the elevation of ROS (reactive oxygen species) and induction of apoptosis in cancer cells [6-11]. However, 
the applications of BA are limited due to its poor water solubility, modest therapeutic effectiveness, poor bioavailability, inappropriate tissue distribution, and short plasma half-life [12]. Recently, various BA-based nanoformulations have been designed and developed to improve its oral bioavailability and enhance its therapeutic effectiveness [13-15]; however, most of them are not responsive to specific tumor microenvironments and, thus, are not sufficiently selective to exert potent cytotoxicity against tumor cells.

Chemodynamic therapy (CDT) has received great attention since the Fenton reaction was first employed to elevate intracellular oxidative stress by converting intratumoral or intracellular hydrogen peroxide $\left(\mathrm{H}_{2} \mathrm{O}_{2}\right)$ into hydroxyl radicals $(\cdot \mathrm{OH})$ to kill cancer cells [16-18]. The tumor microenvironment (TME) involves acidity ( $\mathrm{pH} \sim 6.0-6.5)$ [19] and the overproduction of $\mathrm{H}_{2} \mathrm{O}_{2}(\sim 50-100 \mu \mathrm{M})$ due to mitochondrial dysfunction [20], which can activate the Fenton reaction. Therefore, the short half-life and high oxidation ability of $\cdot \mathrm{OH}$ induced via Fenton reaction only generates and performs the effective damage at the tumor site, avoiding side effects to surrounding tissues [21]. However, the mild acidity of the tumor microenvironment is not the ideal $\mathrm{pH}$ for the Fenton reaction (optimal $\mathrm{pH}$ is 2 4) [10]. Moreover, the overexpressed $\mathrm{H}_{2} \mathrm{O}_{2}$ in the TME is not sufficient to produce the high levels of $\cdot \mathrm{OH}$ in succession for cancer treatments. Glucose oxidase (GOx) can selectively catalyze the oxidation of glucose into gluconic acid and $\mathrm{H}_{2} \mathrm{O}_{2}$ with high efficiency [22,23], which is the perfect characteristic for improving acidity and $\mathrm{H}_{2} \mathrm{O}_{2}$ levels in tumors and, thus, improving the CDT via the Fenton reaction [24]. Moreover, cancer cells express an exceeding desire for glucose to supply energy for proliferation, and are more sensitive to changes in glucose concentration than normal cells, depending on the Warburg effect $[25,26]$. Thus, the depletion of intratumoral glucose by GOx can effectively consume the energy for tumor growth and starve them to death, while also improving the effects of CDT [27].

Supramolecular nanoparticles constructed via non-covalent interactions have attracted widespread attention in the field of drug delivery, due to their simple synthesis procedure, reversibility, and switchable structures [28]. Moreover, they are sensitive to stimuli, with notable responsiveness [29,30]. Pillararenes, the fifth generation of supramolecule, can serve as hosts and bind with the specific functional group of various guests via hydrogen bonding, covalent bonding, $\pi-\pi$ stacking interaction, electrostatic interaction, and ionic interaction [31-34], showing better stability and bioactivity [35-40].

Therefore, the tumor microenvironment (high GSH and ROS)-responsive supramolecular nanoparticles were designed and constructed via the host-guest interactions of water soluble pillar[6]arene with the ferrocene-modified anticancer product BA prodrug (BA-G). Thioether has been employed to bridge ferrocene and the natural anticancer product BA, which can be highly effectively triggered by both the high GSH and ROS in the tumor microenvironment for drug delivery [41]. Then, the encapsulation of GOx in the nanoparticles not only depletes glucose to starve cancer cells, but also improves acidity and $\mathrm{H}_{2} \mathrm{O}_{2}$ levels in tumors, thus improving the CDT to produce hydroxyl radicals with high oxidation ability for killing cancer cells. The thioether-bridged BA prodrug could be a response to the TME, and the release of BA can exert chemotherapy via the elevation of ROS in cancer cells. The novel supramolecular nanoparticles can be tailored to the specific tumor microenvironment, not only improving the efficacy of tumor inhibition while reducing biological risks and the side effects of BA, but also exerting the multimodal synergistic treatment of chemodynamic/starvation/chemotherapy against cancer cells (Scheme 1). 


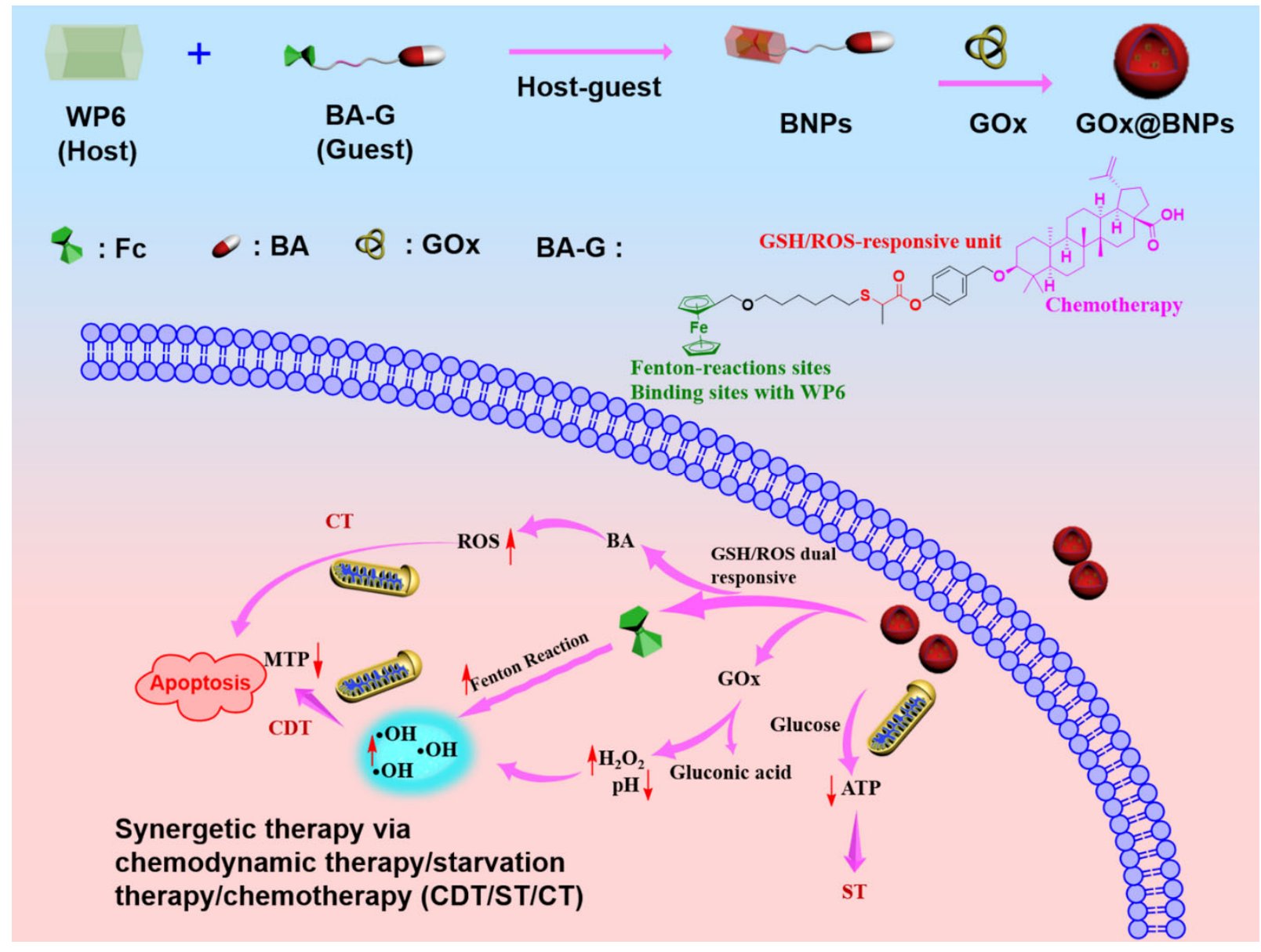

Scheme 1. Schematic illustration of the preparation of supramolecular nanoparticles and their GSH/ROS dual-responsive drug release and anti-proliferative mechanisms against A549 cancer cells.

In this research, WP6 could induce the self-assembly of the nanoparticles via hostguest interactions between the ferrocene moiety of BA-G and WP6. Ferrocene is the binding site. Thioether was employed to bridge ferrocene and the natural anticancer product BA, which can be highly effectively triggered by the high GSH and ROS in the tumor microenvironment for the release of BA. BA induces ROS generation for chemotherapy; GOx consumes glucose to produce $\mathrm{H}_{2} \mathrm{O}_{2}$ and gluconic acid for starvation therapy, and all $\mathrm{H}_{2} \mathrm{O}_{2}$ in the TME and induced by GOx is catalyzed by ferrous ions decomposed from ferrocene to generate the highly toxic $\cdot \mathrm{OH}$ for chemodynamic therapy. Herein, thioether-bridged ferrocene-modified BA-G and the supramolecular nanoparticles GOx@BNPs were prepared, and their GSH/ROS dual-responsive drug release capability and their combination of chemodynamic/starvation/chemotherapy against cancer cells were evaluated in the present study in order to verify these hypotheses.

\section{Results and Discussion}

\subsection{Synthesis of the Host WP6 and Guest BA-G}

The host WP6 was synthesized as described in [42], while the BA prodrug BA-G was obtained by introducing ferrocene for binding sites, thioether as a GSH- and ROSresponsive unit, and BA as an anticancer drug. The synthetic route for guest BA-G is shown in Scheme 2. 

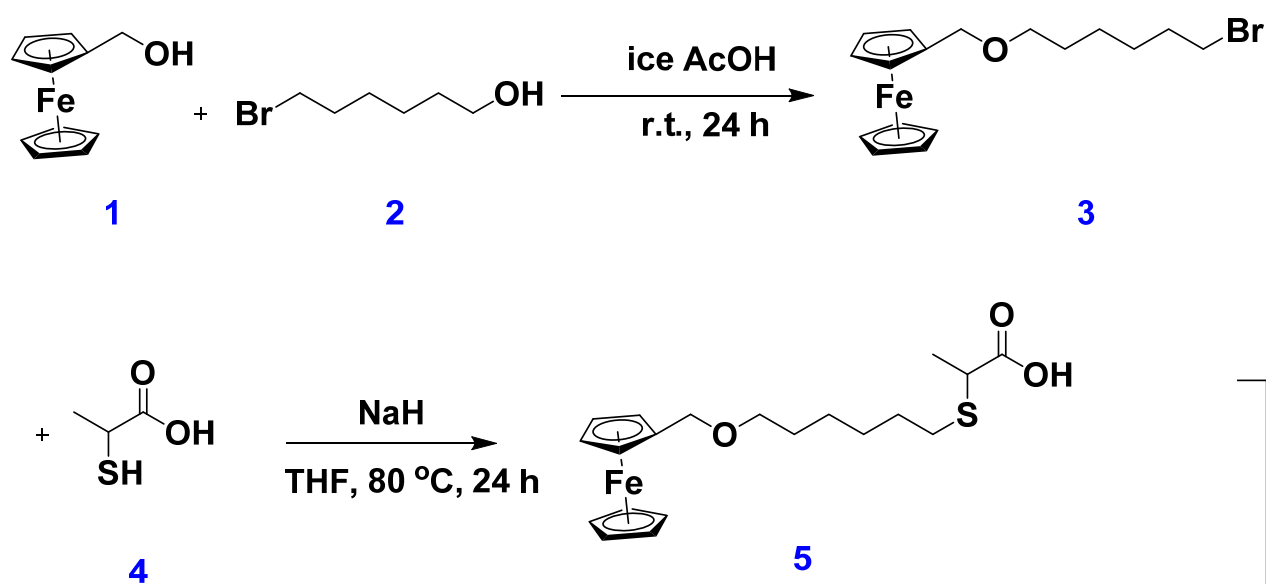<smiles>Cc1ccc(S(=O)(=O)Cl)cc1</smiles>

6<smiles>Cc1ccc(S(=O)(=O)OCc2ccc(OC(=O)C(C)SCCCCCCOCc3ccccc3)cc2)cc1</smiles>

9

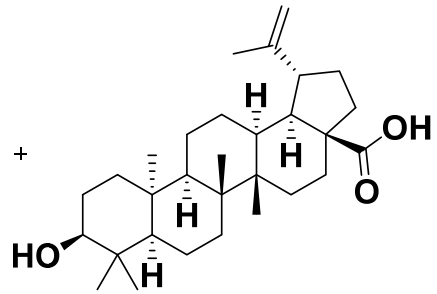

10

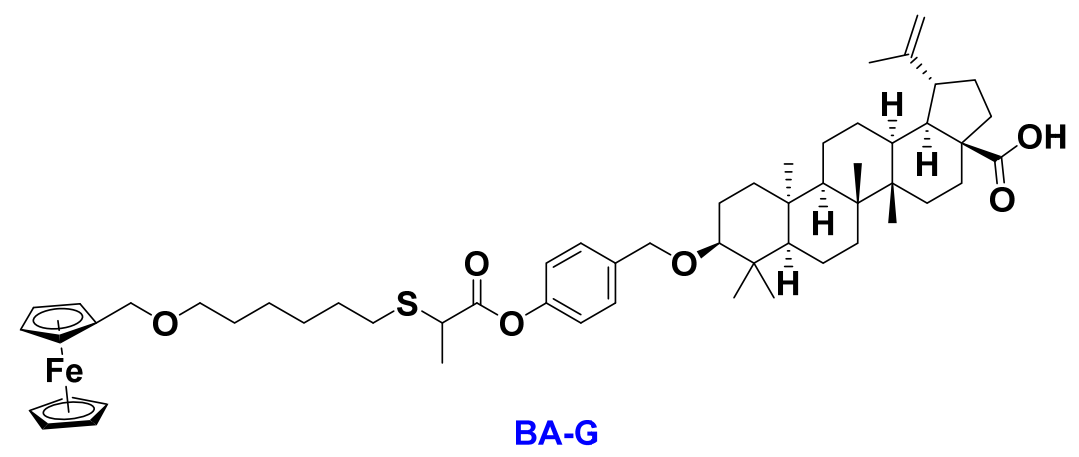

Scheme 2. Synthetic route for the BA prodrug BA-G.

\subsection{Fabrication of Supramolecular Nanoparticles: BNPs and GOx@BNPs}

BNPs were constructed through self-assembly of WP6 and BA-G. The capability to form the nanoassembly was explored based on host-guest interactions between WP6 and BA-G. The aqueous solution (containing 1\% DMSO and 0.5\% DMF as co-solvents, $1 \times 10^{-4} \mathrm{M}$ ) of BA-G remained clear and transparent after two days, and there was no apparent Tyndall effect in the free BA-G aqueous solution. However, a legible Tyndall effect and pale blue opalescence appeared rapidly with the addition of WP6 to the above solution, confirming that WP6 can induce the self-assembly of the nanoparticle via host-guest interactions between the ferrocene moiety of BA-G and WP6. The host-guest inclusion was obtained through the ferrocene moiety of BA-G being fully threaded into the cavity of WP6 in water, in which the driving force was probably from hydrophobic interactions 
and $\pi-\pi$ interactions [43]. Dynamic light scattering (DLS) measurements showed that the diameter and polydispersity (PDI) of the nanoparticles formed by WP6 $\supset$ BA-G were approximately $110.04 \mathrm{~nm}$ and 0.148 , respectively (Figure 1A), in which the molar ratio of BA-G/WP6 was 5:1. The critical aggregation concentration (CAC) at this molar ratio was $2.81 \times 10^{-6} \mathrm{M}$ by the determination of the change in the transmittance at different concentrations (Figure 1C). Electrophoretic light scattering (ELS) demonstrated that the $\zeta$-potential of WP6 $\supset$ BA-G nanoparticles was approximately $-45.50 \mathrm{mV}$ (Figure S6). In addition, these nanoparticles were very stable after 35 days (Figure S7), indicating that these nanoparticles could exist stably. Transmission electron microscopy (TEM) images indicated the formation of numerous nanoparticles, and their diameters were 98-118 nm (Figure 1E). Consequently, these WP6 $\supset$ BA-G nanoparticles with a molar ratio of BA-G/WP6 = 5:1which have the ideal size for passive targeting and can exist stably-were chosen as candidates for further investigation, and abbreviated as BNPs.
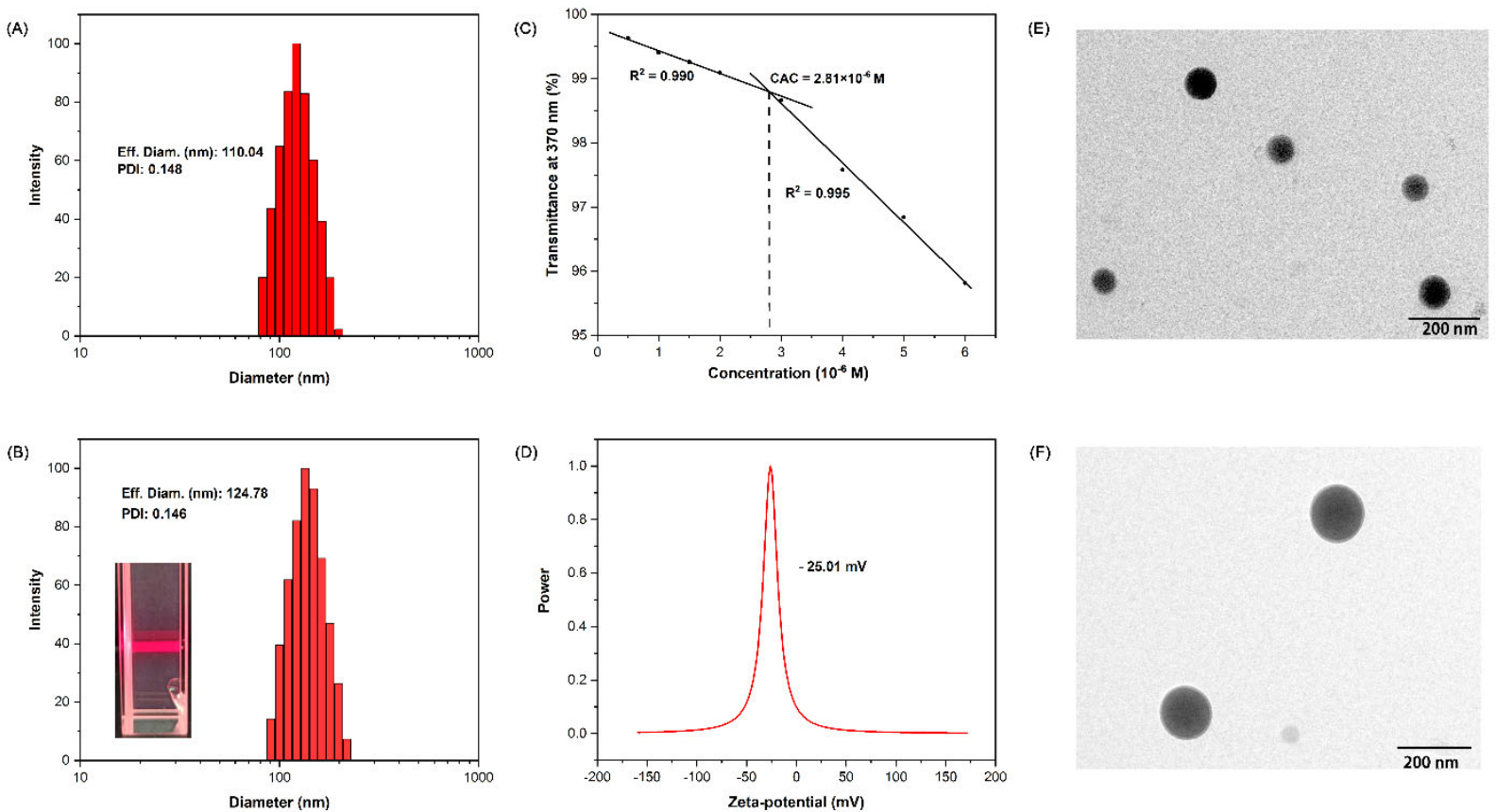

Figure 1. DLS data of (A) BNPs and (B) GOx@BNPs, inset: Tyndall effect of GOx@BNPs; (C) CAC determined by the concentration-dependent optical transmittance of BNPs at $370 \mathrm{~nm}$; (D) $\zeta$-potential of GOx@BNPs; TEM images of (E) BNPs and (F) GOx@BNPs.

GOx-loaded nanoparticles were constructed based on BNPs. After removing the unloaded GOx via dialysis, GOx-loaded nanoparticles were successfully obtained, denoted as GOx@BNPs. The DLS results showed that the diameter of the GOx@BNPs was $124.78 \mathrm{~nm}$ and their PDI was 0.146 (Figure 1B). The $\zeta$-potential was changed to $-25.01 \mathrm{mV}$ (Figure 1D). TEM images indicated the morphology of GOx@BNPs to be a slight oval shape with a diameter from 113 to $136 \mathrm{~nm}$ (Figure 1F). Additionally, the fluorescein-isothiocyanate-labeled glucose oxidase (FITC-GOx)-loaded nanoparticles (FITC-GOx@BNPs) were prepared via the same method, and the capability of GOx loading was determined by loading FITC-labeled GOx using the same method. The maximal loading efficiency and loading content were $20.1 \%$ and $24.5 \%$, respectively.

\subsection{Drug Release Behavior}

Because of the GSH/ROS dual-responsive thioether bond introduced in BA-G, the BA recovery and release behaviors of GOx@BNPs in mimetic normal tissue (low-expressed GSH and $\mathrm{H}_{2} \mathrm{O}_{2}$ ) or the tumor microenvironment (overexpressed GSH and $\mathrm{H}_{2} \mathrm{O}_{2}$ ) were determined via HPLC.GOx@BNPs exhibited satisfactory stability under an artificial healthy 
cell microenvironment (low-expressed GSH and without $\mathrm{H}_{2} \mathrm{O}_{2}$ ). As expected, the release behavior of $\mathrm{BA}$ was only detected in the presence of $\mathrm{GSH}$ or $\mathrm{H}_{2} \mathrm{O}_{2}$, and the release rate was positively correlated with the concentration of $\mathrm{GSH}$ or $\mathrm{H}_{2} \mathrm{O}_{2}$ (Figure 2). At the concentration of $10 \mathrm{mM} \mathrm{GSH}$ and $100 \mu \mathrm{M} \mathrm{H}_{2} \mathrm{O}_{2}$, the amounts of cumulative BA release were $91.68 \%$ and $92.14 \%$, respectively, within $48 \mathrm{~h}$. Meanwhile, in the artificially low-expressed GSH of the healthy cell microenvironment $(5 \mu \mathrm{M})$, the release rate of BA was no more than $10 \%$. This selective drug release and recovery behavior is not only conducive to avoiding damage to normal cells, but can also effectively consume the overexpressed GSH in tumor cells to improve the oxidative stress levels and enhance the CDT's effects.

(A)

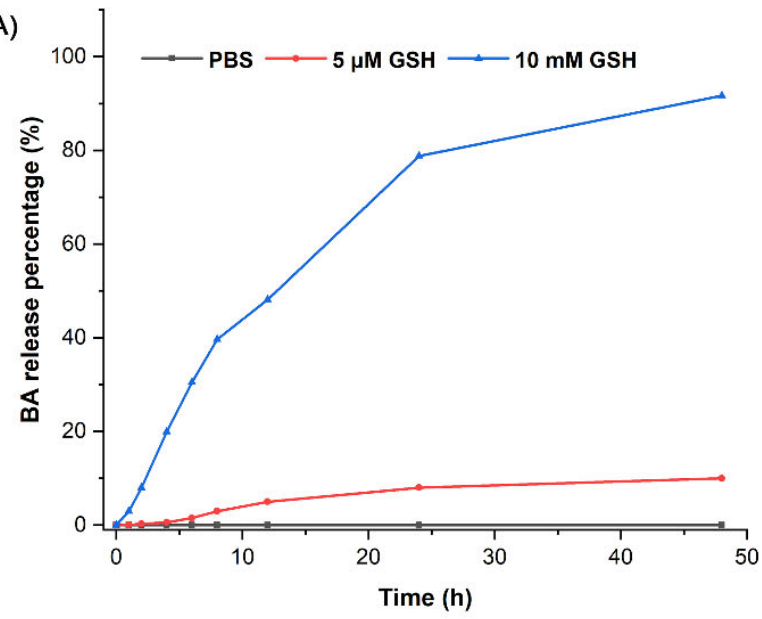

(B)

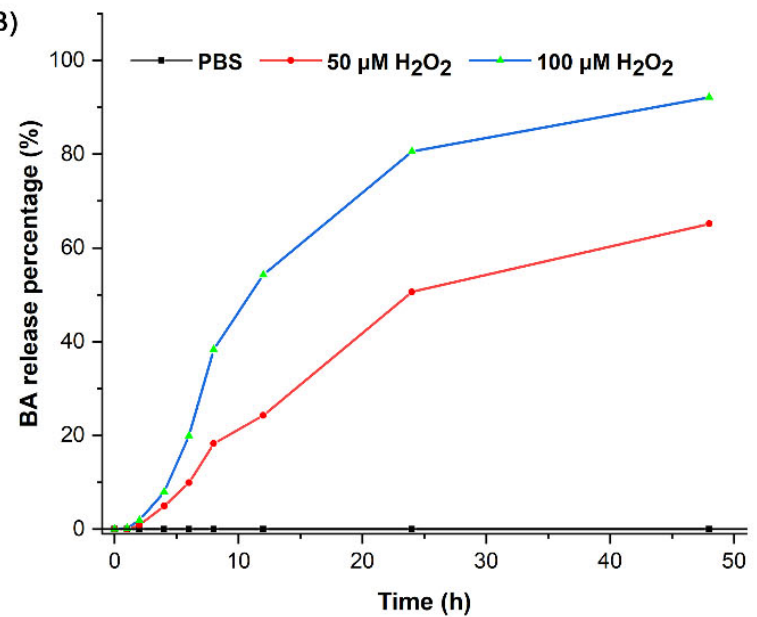

Figure 2. BA release profiles from the GOx@BNPs $(50 \mu \mathrm{M})$ with various concentrations of (A) GSH and $(\mathbf{B}) \mathrm{H}_{2} \mathrm{O}_{2}$ were determined via HPLC.

\subsection{GOx@BNPs Induced Cascade Reactions}

As described in the introduction, GOx@BNPs were intended to catalyze the conversion of glucose to gluconic acid and $\mathrm{H}_{2} \mathrm{O}_{2}$, and then the generated $\mathrm{H}_{2} \mathrm{O}_{2}$ could react with ferrocene to produce hydroxyl radicals $(\cdot \mathrm{OH})$ via cascade reaction under the acidic conditions. To validate the feasibility of cascade reactions induced by GOx@BNPs, we detected the variations in $\mathrm{pH}$ values and $\mathrm{OH}$ production at different levels of glucose. A rapid reduction phenomenon of $\mathrm{pH}$ was found in both GOx@BNPs ( $\mathrm{pH}$ from 7.00 to 2.98) and the native GOx groups ( $\mathrm{pH}$ from 7.00 to 3.02) in the presence of glucose $(1 \mathrm{mg} / \mathrm{mL}$ ). Moreover, the degree of reduction of $\mathrm{pH}$ values was closely related to glucose concentration (Figure $3 \mathrm{~A}$ ). By contrast, almost no apparent change in $\mathrm{pH}$ was monitored in the BNP group. Subsequently, the commercially available probe 3,3',5,5'-tetramethylbenzidine (TMB), along with EPR (electron paramagnetic resonance) spectroscopy, was utilized to identify the production of .OH. As shown, the color of the GOx@BNPs solution darkened gradually from faint yellow to blue (Figure 3B,C); in the meantime, the typical absorbance band of oxidized TMB at $652 \mathrm{~nm}$ enhanced drastically in the presence of glucose (without horseradish peroxidase) with increasing time or levels of glucose (Figure 3D,E). This phenomenon demonstrated efficient $\cdot \mathrm{OH}$ production by GOx@BNPs, and its yield was dependent on glucose consumption. In addition, the EPR results further proved the robust $\cdot \mathrm{OH}$ generation ability, wherein the typical 1:2:2:1 signal of ·OH was found only in the GOx@BNPs group, but not in the native GOx and BNP groups (Figure 3F). Collectively, GOx@BNPs are expected to be a promising candidate for cancer starvation and chemodynamic treatment via cascade reactions. 
(A)

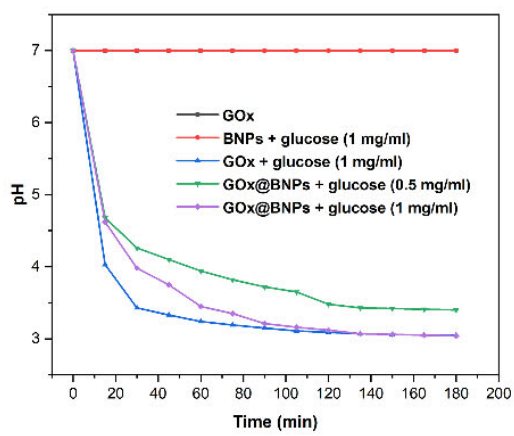

(B)

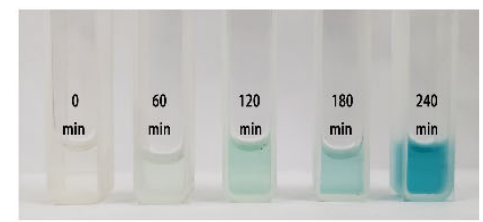

(C)

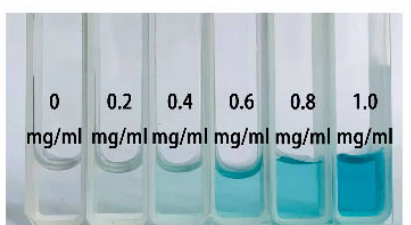

(D)

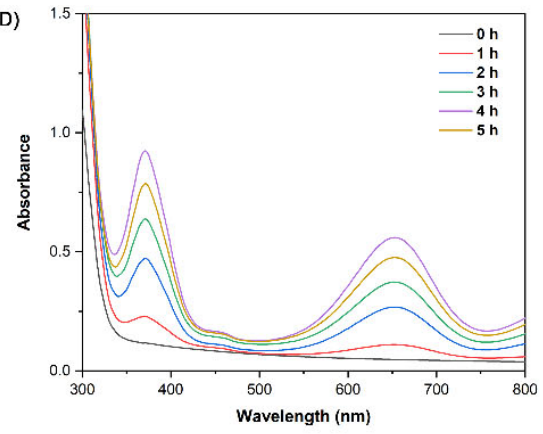

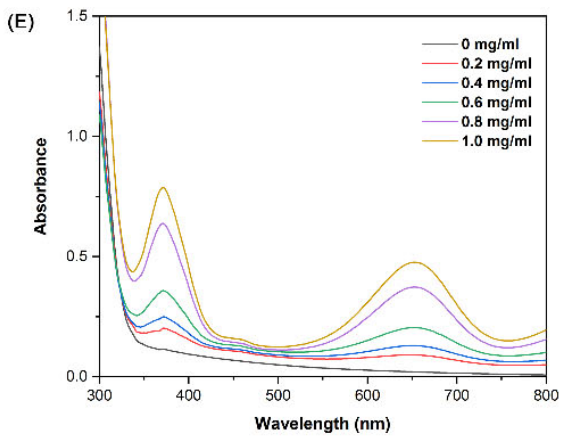

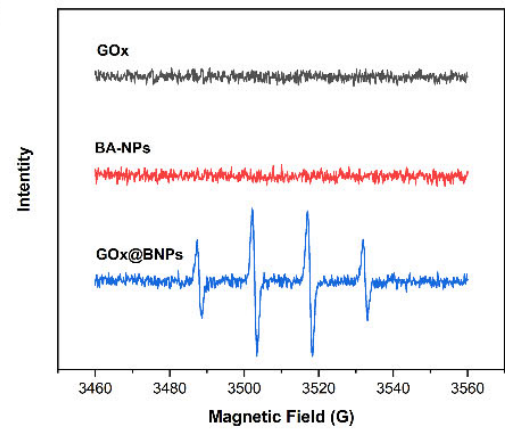

Figure 3. (A) Time-dependent $\mathrm{pH}$ changes of GOx@BNPs $\left(1 \times 10^{-4} \mathrm{M}\right)$ in the presence of glucose. (B) Photograph of GOx@BNPs $\left(1 \times 10^{-4} \mathrm{M}\right)$ in the presence of $1 \mathrm{mg} / \mathrm{mL}$ glucose from 1 to $4 \mathrm{~h}$. (C) Photograph of GOx@BNPs $\left(1 \times 10^{-4} \mathrm{M}\right)$ in the presence of different concentrations of glucose after incubation for $4 \mathrm{~h}$. (D) Time-dependent UV-Vis spectrum changes of GOx@BNPs $\left(1 \times 10^{-4} \mathrm{M}\right)$ in the presence of glucose $(1 \mathrm{mg} / \mathrm{mL})$ and TMB $(1 \mathrm{mM})$. (E) UV-Vis spectrum changes of GOx@BNPs $\left(1 \times 10^{-4} \mathrm{M}\right)$ with TMB $(1 \mathrm{mM})$ and different glucose concentrations after incubation for $4 \mathrm{~h}$. (F) EPR results of different groups in the presence of glucose $(1 \mathrm{mg} / \mathrm{mL})$ for verification of $\cdot \mathrm{OH}$ production.

\subsection{Cytotoxicity of GOx@BNPs}

After verification the capability of GOx@BNPs to induce a cascade reaction and its cellular internalization, the cytotoxicity of GOx@BNPs against human breast cancer cells MCF-7 and human lung cancer cells A549 was evaluated by MTT assay. Considering that the glucose in the culture medium causes problems in the process of cellular internalization for GOx-containing groups, the cultured cells were washed twice with PBS after incubation for $24 \mathrm{~h}$, and then incubated with glucose/serum-free media for $2 \mathrm{~h}$, after which $100 \mu \mathrm{L}$ of fresh glucose/serum-free medium containing different concentrations of BA, BNPs, GOx, or GOx@BNPs was used to treat cells for $4 \mathrm{~h}$. Afterwards, any undelivered agent was fully removed by washing with PBS, before replacing the glucose-containing medium to culture for $24 \mathrm{~h}$ in order to determine the anticancer efficiency. As shown in Figure $4 \mathrm{~A}, \mathrm{~B}$, the BNP-, GOx-, and GOx@BNPs-treated groups all expressed significant proliferation inhibition ability in a concentration-dependent manner-much more potent than that of the BA-treated group. The maximum inhibition rates of GOx@BNPs against MCF-7 and A549 cancer cells were $91.99 \%$ and $95.63 \%$, respectively, at the concentration of $20 \mu \mathrm{M}-$ much more potent than the results of any of the other treatment groups. Since the cytotoxicity of GOx@BNPs against A549 is higher than that of MCF-7, A549 was chosen for further study. 
(A)



(B)

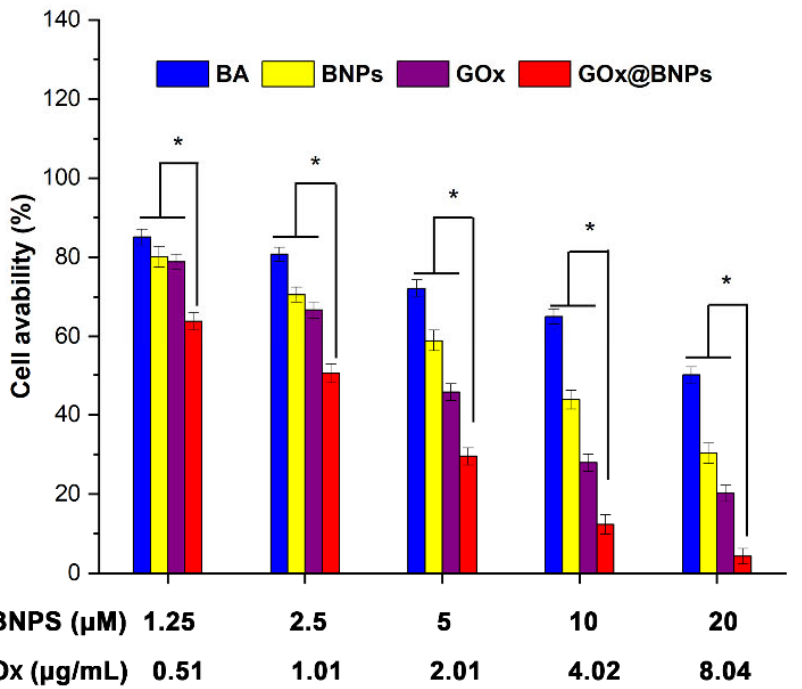

Figure 4. In vitro cytotoxicity of different groups against (A) MCF-7 and (B) A549 cancer cells at $37{ }^{\circ} \mathrm{C}$ for $24 \mathrm{~h}$ by intracellular drug delivery $\left({ }^{*} p<0.05\right)$.

Furthermore, the live/dead cell staining assays were performed direct visualization of the anti-proliferative activity of GOx@BNPs against A549 cells, in which the live cells were stained as green fluorescence while the dead cells were stained as red fluorescence after treatment. As depicted in Figure 5, the PBS groups showed no detectable damage to A549 cells, but almost no live cells were found in the GOx@BNPs groups after $24 \mathrm{~h}$ of administration, which was consistent with the results of the MTT assays. From these results, we deduce that the outstanding anti-proliferative activity of GOx@BNPs comes from the synergistic combination of starving therapy (GOx), chemodynamic therapy $(\cdot \mathrm{OH})$, and chemotherapy (BA), as triggered by intracellular cascade reactions.

Bright
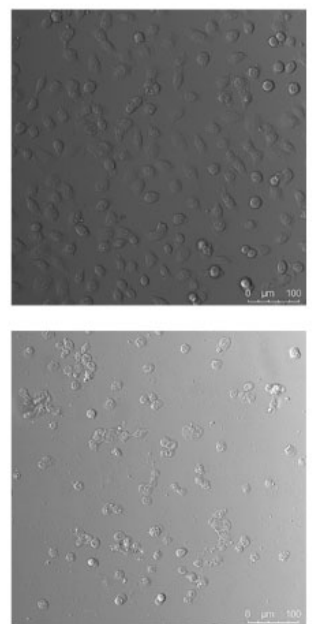

Calcein-AM
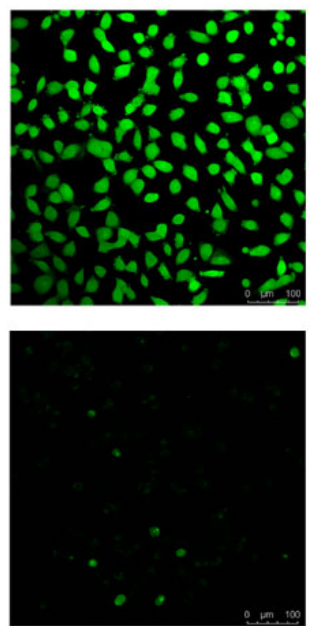

PI
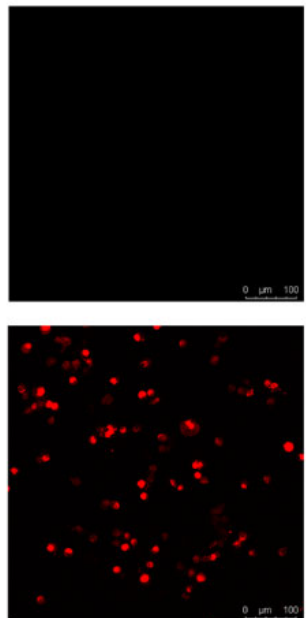

Merged
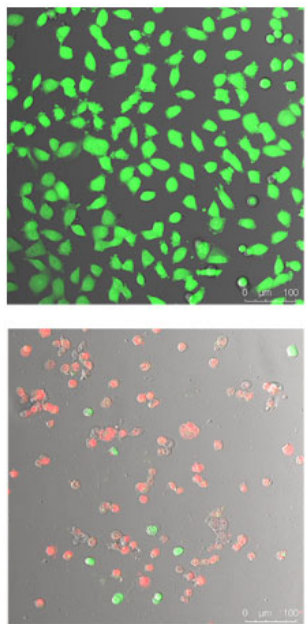

Figure 5. Live/dead A549 cells' staining after treatment with PBS or GOx@BNPs $(10 \mu \mathrm{M})$ at $37^{\circ} \mathrm{C}$ for $12 \mathrm{~h}$ in the presence of glucose $(1 \mathrm{mg} / \mathrm{mL})$. Scale bars: $100 \mu \mathrm{m}$. 


\subsection{Cellular Internalization and Subcellullar Distribution}

FITC-GOx@BNPs in A549 cells were explored via confocal laser scanning microscopy. After co-incubation for $1 \mathrm{~h}$, the intracellular green fluorescence of FITC-GOx was distinctly seen, while merged yellow fluorescence was also observed. When the co-culture was extended to $2 \mathrm{~h}$, the green fluorescence was better distributed throughout the cells than after incubation for just $1 \mathrm{~h}$ (Figure 6). These results indicate that GOx@BNPs could be successfully internalized by cancer cells through endocytosis, enabling them to execute effective intracellular delivery for cancer treatment.

\section{Lysotracker}

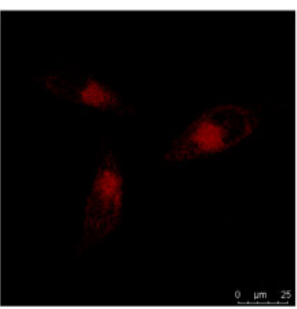

$1 \mathrm{~h}$

$2 \mathrm{~h}$

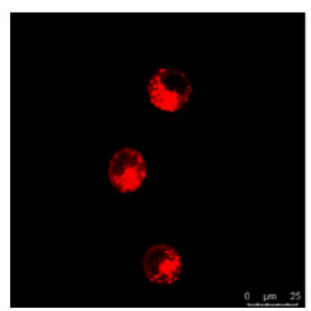

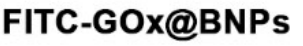
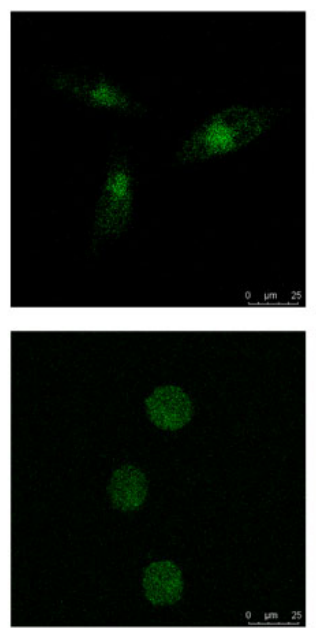

Hochest
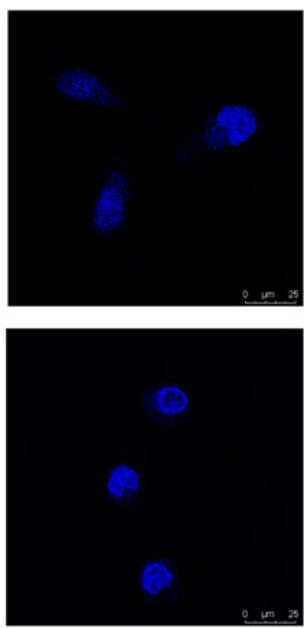

Merged
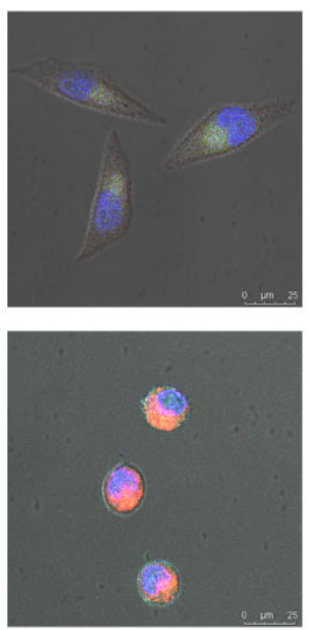

Bright field
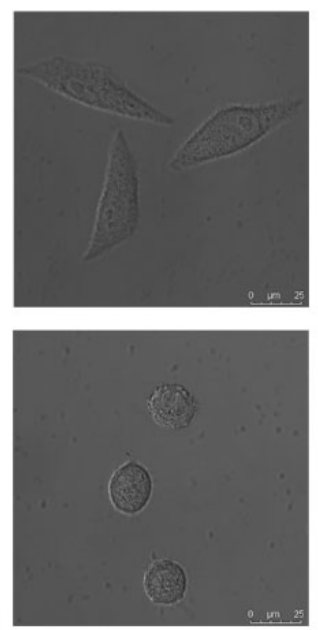

Figure 6. Confocal fluorescence imaging of FITC-GOx@BNPs $(10 \mu \mathrm{M})$ in A549 cells at $37^{\circ} \mathrm{C}$ for $1 \mathrm{~h}$ and $2 \mathrm{~h}$. Scale bars: $25 \mu \mathrm{m}$.

\subsection{Mechanism of Cancer Inhibition}

\subsubsection{Elevation of ROS}

ROS play an important role in redox signaling pathways, which are a promising target for the treatment of multiple types of cancers [44-46]. Fenton-reaction-based CDT can generate ROS, which can damage the cancer cells directly [47]. To explore the inferred mechanism of cell death induced by GOx@BNPs, the levels of intracellular ROS-a significant indicator associated with CDT-were first investigated with the assistance of the ROS detector DCFH-DA. As shown in Figure 7A,B, no fluorescence signal was detected in the PBS groups; however, a very bright green fluorescence was found in the BA-, GOx-, and GOx@BNPs-treated A549 cells, and the fluorescence intensity of the GOx@BNPs-treated group was much stronger than that of both the BA- and GOx-treated groups, demonstrating the much more efficient ·OH production ability of GOx@BNPs in A549 cancer cells. 
(A)

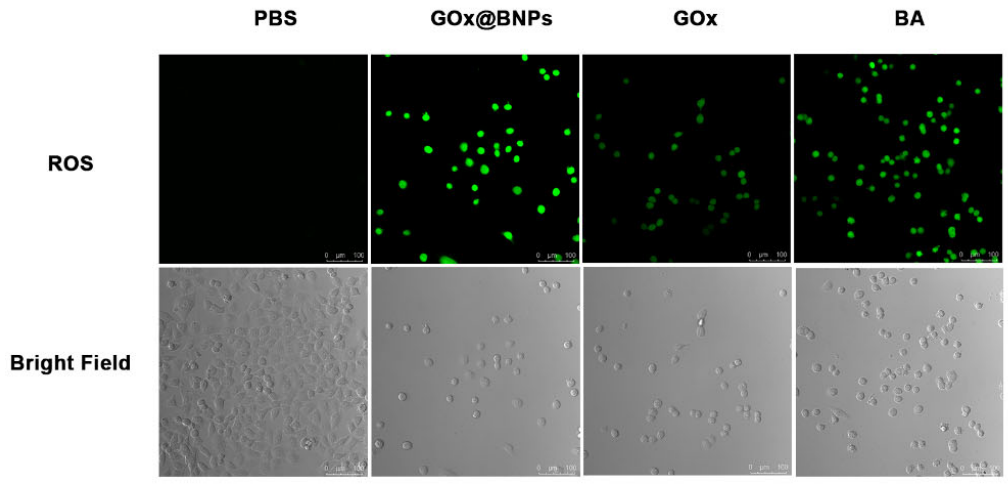

(B)

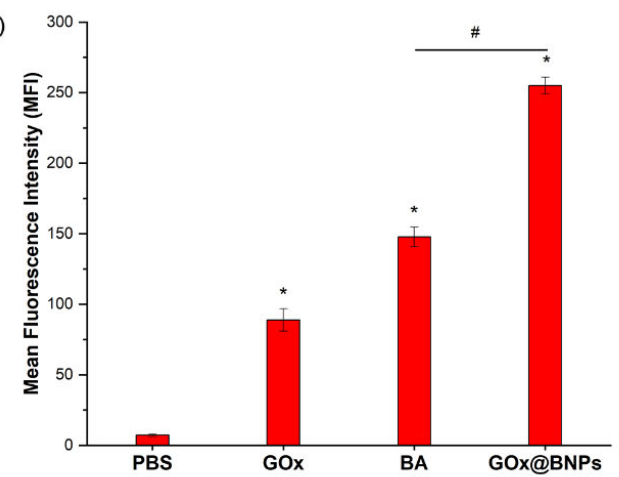

(C)

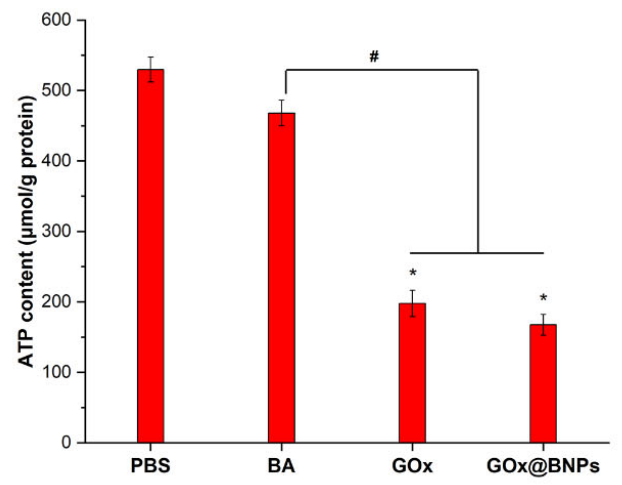

Figure 7. (A) ROS measurement in A549 cells using the DCFH-DA probe after incubation with different groups at $37^{\circ} \mathrm{C}$ for $2 \mathrm{~h}$. Scale bars: $100 \mu \mathrm{m}$. (B) The corresponding mean fluorescence intensity (MFI) after incubation with different groups (* $p$, $\left.{ }^{\#} p<0.05\right)$. (C) Intracellular ATP levels of A549 cells after treatment with different groups at $37^{\circ} \mathrm{C}$ for $12 \mathrm{~h}\left({ }^{*} p,{ }^{\#} p<0.05\right)$. Results are expressed as the mean \pm S.D. $(n=3)$.

\subsubsection{Decrease in ATP}

As mentioned above, GOx could selectively catalyze the oxidation of glucose into gluconic acid and $\mathrm{H}_{2} \mathrm{O}_{2}$ with high efficiency; hence, the depletion of intratumoral glucose by GOx can effectively consume the energy for tumor growth and starve tumors to death. We further measured the intracellular ATP content, which can effectively reflect the effects of starvation therapy. As shown in Figure 7C, the intracellular ATP concentration was $167.44 \mu \mathrm{mol} / \mathrm{g}$ protein after administration of GOx@BNPs, which is lower than that of GOx (197.78.23 $\mu \mathrm{mol} / \mathrm{g}$ protein), and much lower than those of PBS (529.60 $\mu \mathrm{mol} / \mathrm{g}$ protein) and BA (468.06 $\mu \mathrm{mol} / \mathrm{g}$ protein) groups. This remarkable ATP consumption behavior confirms the starvation therapy effect of GOx@BNPs on cancer cells.

\subsubsection{Evaluation of Mitochondrial Transmembrane Potential (MTP)}

The MTP of A549 in the GOx@BNPs-treated group was assessed after staining with JC-1 using flow cytometric analysis. In normal mitochondria, JC-1 aggregates in the mitochondrial matrix to form J-aggregate, which exhibits a strong red fluorescence; however, it will emit green fluorescence at a low MTP [48]. After incubation with different groups for $24 \mathrm{~h}$, A549 cells were then incubated with JC- 1 at $37^{\circ} \mathrm{C}$ for $15 \mathrm{~min}$ and, finally, detected via flow cytometry. The mitochondria of healthy cells containing red JC- 1 aggregates were detected by the FL2 channel, while the mitochondria of damaged cells containing the green JC-1 monomers were detected by the FL1 (FITC) channel. The decrease in MTP is indicated by an increase in the percentage of green fluorescence cells. As shown in Figure 8, the percentages of green fluorescence cells in the BA-, GOx-, and GOx@BNPs-treated groups were much higher than that of PBS-treated group, demonstrating that the MTP was significantly decreased. Among them, the MTP of the GOx@BNPs-treated group was the lowest, with a much more potent decrease than that of the BA- and GOx-treated groups. 
(A)

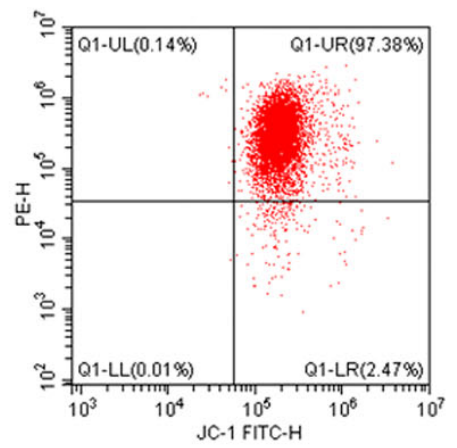

(C)

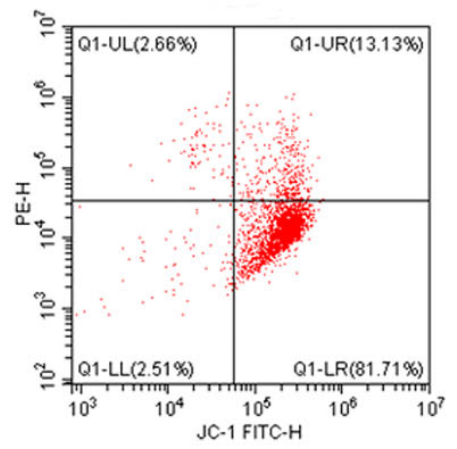

(B)

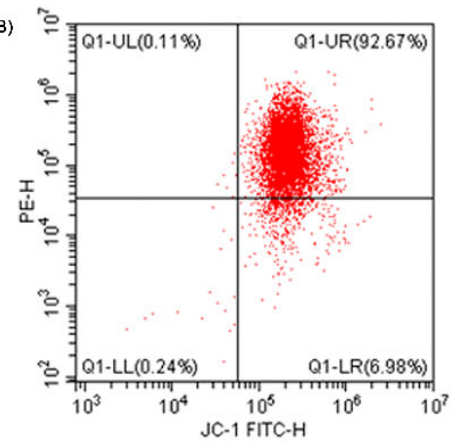

(D)

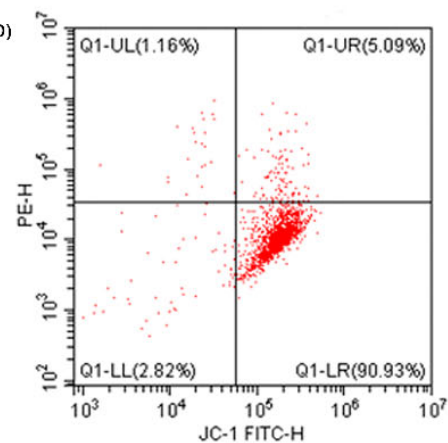

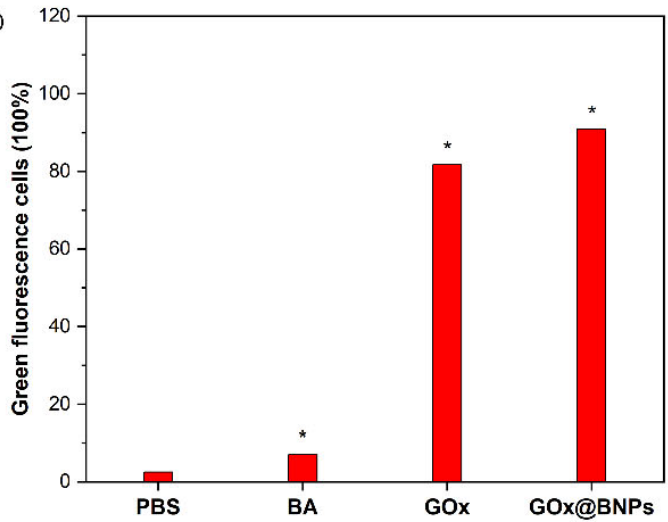

Figure 8. Representative flow cytometric analysis of JC-1-stained A549 cells treated with (A) PBS; (B) BA; (C) GOx; and (D) GOx@BNPs. (E) Statistical analysis of A549 cells treated with different groups $\left({ }^{*} p<0.05\right)$. A549 cells were treated with different groups for $24 \mathrm{~h}$, and then incubated with JC- 1 at $37^{\circ} \mathrm{C}$ for $15 \mathrm{~min}$ and, finally, detected via flow cytometry. The decrease in MTP is indicated by an increase in the percentage of green fluorescence cells.

\subsubsection{Induction of Apoptosis}

BA can act as an apoptosis activator to exert an anticancer effect [49]. Eventually, the apoptosis of A549 cancer cells treated with different groups was evaluated via flow cytometry. As shown in Figure 9, the BA-, GOx-, and GOx@BNPs-treated groups all significantly induced cell apoptosis compared to the PBS-treated group. The apoptosis rates of both the GOx@BNPs- $(93.26 \%)$ and GOx (79.92\%)-treated groups were much higher than that of the BA-treated group $(9.44 \%)$. Among the various groups, GOx@BNPs induced the highest apoptosis rate through intracellular drug delivery.

As mentioned above, this work presents a novel method to regulate the tumor microenvironment for improved CDT and the preparation of novel GSH/ROS dual-responsive supramolecular nanoparticles, which can exert significant cytotoxicity against cancer cells through the synergistic interaction of chemodynamic therapy, starvation therapy, and chemotherapy. For example, BA can induce elevated ROS in cancer cells, as is clearly demonstrated in Figure 7A,B. Compared to the PBS-treated group, a very bright green fluorescence was found in the BA- and GOx-treated groups, and the fluorescence intensity of the GOx@BNPs-treated group was much stronger than that of both the BA- and GOxtreated groups, demonstrating that GOx@BNPs induced potent ROS elevation in A549 cancer cells through the synergistic interaction of the chemotherapy of BA and the Fentonreaction-based chemodynamic therapy. The preliminary research mechanism shows that the dramatic suppression of cancer cell growth induced by GOx@BNPs was derived from the elevation of ROS, decrease in ATP and MTP and, finally, cell apoptosis. However, in order to explain the findings better, more related mechanisms must be explored in the remainder of this study. Although this kind of nanoparticle has the ideal size for passive targeting, it is still better to introduce an active targeting group in the supramolecular nanoparticles so as to enable active targeting of the nanoparticles for further study. In an effort to verify whether the GOx@BNPs could specifically respond to the overexpressed 
GSH and ROS in the TME, the cytotoxicity of GOx@BNPs against human normal cells, as well as their antitumor activity in vivo, will be evaluated in the remainder of this study.

(A)

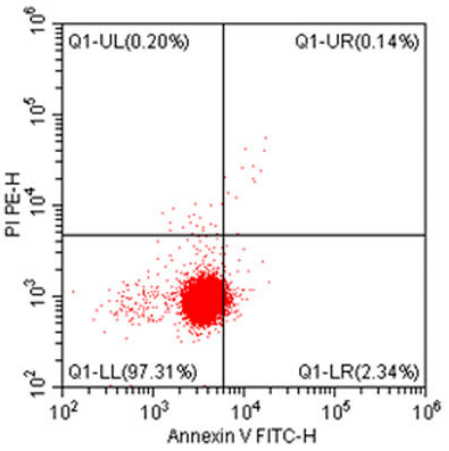

(C)



(B)

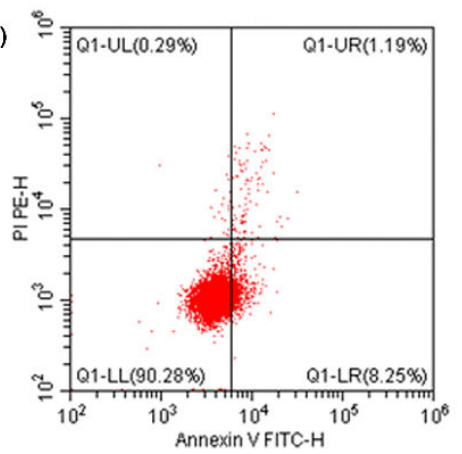

(D)

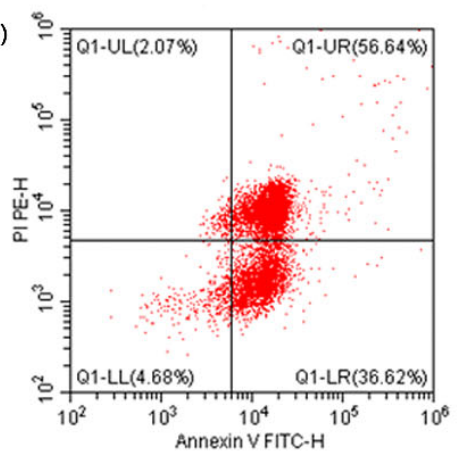

(E)

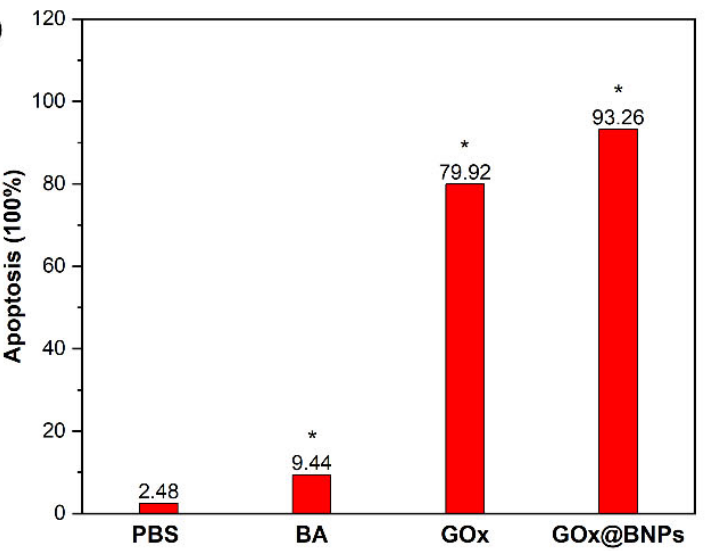

Figure 9. Representative graphs and statistical analysis of Annexin V-FITC/PI staining. Flow cytometric analysis of Annexin V-FITC/PI stained A549 cells treated with (A) PBS; (B) BA; (C) GOx; and (D) GOx@BNPs. (E) Statistical analysis the apoptosis rates of $\mathrm{A} 549$ cells at $37^{\circ} \mathrm{C}$ for $12 \mathrm{~h}$. Inserted numbers in the profiles indicate the percentage of the cells present in this area. Date are expressed as the mean \pm S.D., $n=3\left({ }^{*} p<0.05\right)$.

\section{Materials and Methods}

\subsection{General Information}

All reagents were purchased commercially and used without further purification unless otherwise noted. All reactions were performed in a normal air atmosphere unless otherwise stated. Glucose oxidase (GOx, 100 unit/mg protein) was purchased from SigmaAldrich. Column chromatography was performed with silica gel (200-300 mesh) produced by Qingdao Marine Chemical Factory, Qingdao (China). NMR spectra were recorded on a Bruker DPX $400 \mathrm{MHz}$ spectrometer using the internal standard tetramethylsilane (TMS). HRMS data were recorded on a JMS-SX102A (FAB) or via LC/MSD TOF. Dynamic light scattering (DLS) measurements were taken using a NanoBrook 90Plus Zeta (Brookhaven Instruments Corporation, New York, NY, USA) with a $200 \mathrm{~mW}$ polarized laser source $(\lambda=514 \mathrm{~nm})$. Zeta potential measurements were recorded at $25^{\circ} \mathrm{C}$ using a NanoBrook 90Plus Zeta (Brookhaven Instruments Corporation, New York, NY, USA). Transmission electron microscope (TEM) imaging was performed using a HITACHI HT-7700 instrument. The UV-Vis absorption spectra were recorded on a spectrometer (UV1800PC, Jinghua, Shanghai, China). The EPR (electron paramagnetic resonance) spectra were recorded on JON Bruker BioSpin GmbH. The excitation and emission spectra were measured on a SHIMADZU RF-5301PC fluorescence spectrometer.

\subsection{Preparation of $B A-G$}

\subsubsection{Synthesis of Compound 3}

Ferrocene methanol 1 (1.0803 g, $5 \mathrm{mmol}$ ), 2,2'-(ethane-1,2-diylbis(oxy))bis(ethan-1-ol) $2(3.0034 \mathrm{~g}, 20 \mathrm{mmol})$, and $\mathrm{Al}(\mathrm{OTf})_{3}(48 \mathrm{mg}, 0.1 \mathrm{mmol})$ were suspended in anhydrous dichloromethane. After the mixture was stirred at ambient temperature for $6 \mathrm{~h}$, an ap- 
propriate amount of $5 \% \mathrm{Na}_{2} \mathrm{CO}_{3}$ was then added, and the mixture was extracted with $\mathrm{CH}_{2} \mathrm{Cl}_{2}$ (3 times with $10 \mathrm{~mL}$ ). The combined organic layer was washed with brine, dried with anhydrous sodium sulfate, and filtered, and the solvent was removed via evaporation in vacuum. The crude products were purified via column chromatography using ethyl acetate/petroleum ether $(1: 5, v / v)$ as an eluent to produce target compound 3 as a clear, pale yellow oil $(1.2188 \mathrm{~g}, 3.5 \mathrm{mmol}, 70 \%) .{ }^{1} \mathrm{H} \mathrm{NMR}\left(400 \mathrm{MHz}, \mathrm{CDCl}_{3}\right), \delta 4.34(\mathrm{~d}, J=4.7 \mathrm{~Hz}$, $2 \mathrm{H}), 4.24-4.23(\mathrm{~m}, 2 \mathrm{H}), 4.17-4.11(\mathrm{~m}, 7 \mathrm{H}), 3.74-3.70(\mathrm{~m}, 2 \mathrm{H}), 3.68-3.57(\mathrm{~m}, 10 \mathrm{H})$. The ${ }^{1} \mathrm{H}$ NMR spectra of compound 3 are available in Figure S1.

\subsubsection{Synthesis of Compound 5}

$\mathrm{NaH}(0.6 \mathrm{~g}, 25 \mathrm{mmol})$ and compound $4(0.53 \mathrm{~g}, 5 \mathrm{mmol})$ were suspended in anhydrous THF under a nitrogen atmosphere and stirred for $30 \mathrm{~min}$ at $80^{\circ} \mathrm{C}$. Then, compound $3(2 \mathrm{~g}$, $5.5 \mathrm{mmol}$ ) dissolved in anhydrous THF was added to the suspension, and the reaction mixture was continuously stirred for $24 \mathrm{~h}$ at $80^{\circ} \mathrm{C}$. After the mixture was cooled to room temperature, a large amount of water was added to quench the reaction. The water layer was first extracted with EA and then acidified to $\mathrm{pH}$ 5-6 with $2 \mathrm{~mol} / \mathrm{L}$ hydrochloric acid, and finally extracted with EA ( 3 times with $30 \mathrm{~mL}$ ). The combined organic layer was washed with brine, dried with anhydrous sodium sulfate, and filtered, and the solvent was removed via evaporation in vacuum to produce target compound 5 as a clear, pale yellow oil (1.4252 g, $3.5 \mathrm{mmol}, 70 \%)$.

\subsubsection{Synthesis of Compound 8}

Compound $6(0.62 \mathrm{~g}, 5 \mathrm{mmol})$ and DIPEA $(1.65 \mathrm{~mL}, 10 \mathrm{mmol})$ were dissolved in anhydrous dichloromethane, and then compound $7(1.14 \mathrm{~g}, 6 \mathrm{mmol})$ was added in an ice bath. The mixture was stirred for $2 \mathrm{~h}$ at $25^{\circ} \mathrm{C}$ and extracted with $\mathrm{CH}_{2} \mathrm{Cl}_{2}$ ( 3 times with $10 \mathrm{~mL}$ ). The combined organic layer was washed with brine, dried with anhydrous sodium sulfate, and filtered, and the solvent was removed via evaporation in vacuum. The crude products were purified via column chromatography using ethyl acetate/petroleum ether $(1: 5, v / v)$ as an eluent to produce target compound 8 as a clear, pale yellow oil (1.11 g, $4.0 \mathrm{mmol}, 80 \%)$.

\subsubsection{Synthesis of Compound 9}

Compound 5 (70 mg, $0.17 \mathrm{mmol}), \mathrm{EDCI}(65.2 \mathrm{mg}, 0.34 \mathrm{mmol})$, and DMAP (4.15 mg, $0.034 \mathrm{mmol}$ ) were suspended in anhydrous dichloromethane. The mixture was stirred at room temperature for 30 minutes, then compound $8(57 \mathrm{mg}, 0.2 \mathrm{mmol})$ dissolved in anhydrous dichloromethane was slowly added. The reaction mixture was further stirred at room temperature for $12 \mathrm{~h}$, and then extracted with dichloromethane. The organic layer was washed with brine, dried with anhydrous sodium sulfate, and filtered, and the solvent was removed via evaporation in vacuum. The crude products were purified by column chromatography using ethyl acetate/ petroleum ether $(1: 9, v / v)$ as an eluent to produce target compound 9 as a clear, pale yellow oil $(80 \mathrm{mg}, 0.12 \mathrm{mmol}, 70 \%)$. ${ }^{1} \mathrm{H}$ NMR $\left(400 \mathrm{MHz}, \mathrm{CDCl}_{3}\right), \delta 7.64(\mathrm{~d}, J=8.3 \mathrm{~Hz}, 2 \mathrm{H}), 7.26-7.20(\mathrm{~m}, 4 \mathrm{H}), 6.91(\mathrm{~d}, J=8.6 \mathrm{~Hz}$, $2 \mathrm{H}), 5.04(\mathrm{~d}, J=4.9 \mathrm{~Hz}, 2 \mathrm{H}), 4.19(\mathrm{~s}, 2 \mathrm{H}), 4.15(\mathrm{~s}, 2 \mathrm{H}), 4.05(\mathrm{~s}, 7 \mathrm{H}), 3.34-3.30(\mathrm{~m}, 3 \mathrm{H})$, $2.46(\mathrm{~d}, J=7.3 \mathrm{~Hz}, 2 \mathrm{H}), 2.38(\mathrm{~s}, 3 \mathrm{H}), 1.45(\mathrm{~s}, 4 \mathrm{H}), 1.37(\mathrm{~d}, J=7.1 \mathrm{~Hz}, 3 \mathrm{H}), 1.23-1.19(\mathrm{~m}, 6 \mathrm{H})$. The ${ }^{1} \mathrm{H}$ NMR spectra of compound 9 are available in Figure S2.

\subsubsection{Synthesis of Copound BA-G}

Betulinic acid $(0.47 \mathrm{~g}, 1 \mathrm{mmol})$, compound $9(0.80 \mathrm{~g}, 1.2 \mathrm{mmol})$, and $\mathrm{K}_{2} \mathrm{CO}_{3}(0.28 \mathrm{~g}$, $2 \mathrm{mmol}$ ) were suspended in anhydrous DMF and anhydrous acetonitrile, and then the mixture was stirred for $12 \mathrm{~h}$ at $50{ }^{\circ} \mathrm{C}$. After the reaction mixture was allowed to cool to room temperature, an appropriate amount of cold water was added, and the white solid was precipitated and filtered, washed with $\mathrm{PE}$, and dried in vacuum, and the product was formed as a pale yellow solid $(0.81 \mathrm{~g}, 0.85 \mathrm{mmol}, 85 \%) .{ }^{1} \mathrm{H}$ NMR $\left(400 \mathrm{MHz}, \mathrm{CDCl}_{3}\right)$, $\delta 4.66(\mathrm{~s}, 1 \mathrm{H}), 4.53(\mathrm{~s}, 1 \mathrm{H}), 4.19(\mathrm{~s}, 2 \mathrm{H}), 4.16(\mathrm{~s}, 2 \mathrm{H}), 4.06(\mathrm{~s}, 7 \mathrm{H}), 3.99(\mathrm{~d}, J=9.0 \mathrm{~Hz}, 2 \mathrm{H})$, 
3.35-3.32 (m, 2H), $3.11(\mathrm{~d}, J=6.2 \mathrm{~Hz}, 1 \mathrm{H}), 2.93(\mathrm{~d}, J=4.6 \mathrm{~Hz}, 1 \mathrm{H}), 1.80(\mathrm{~d}, J=9.8 \mathrm{~Hz}, 4 \mathrm{H})$, $1.52(\mathrm{~d}, J=11.5 \mathrm{~Hz}, 12 \mathrm{H}), 1.29(\mathrm{~s}, 16 \mathrm{H}), 1.18(\mathrm{~s}, 6 \mathrm{H}), 0.89(\mathrm{~s}, 7 \mathrm{H}), 0.84-0.77(\mathrm{~m}, 9 \mathrm{H}), 0.75$ (s, 3H), 0.69 (s, 3H). $\left.{ }^{13} \mathrm{C} \mathrm{NMR} \mathrm{(101} \mathrm{MHz,} \mathrm{CDCl}_{3}\right), \delta 175.2,149.6,108.5,77.9,68.8,68.4,68.1$, $67.4,62.9,55.5,54.3,49.5,48.4,46.0,41.4,39.7,37.8,37.7,37.3,36.2,36.0,33.3,31.2,29.6,28.6$, $27.7,26.9,26.4,24.9,24.8,24.5,19.9,18.3,17.3,15.1,14.9,14.3,13.7$. HRMS $m / z 949.5103$ $[\mathrm{M}+\mathrm{H}]^{+}$(calculated for $\mathrm{C}_{15} \mathrm{H}_{15} \mathrm{O}^{+}$, 949.5103). The NMR and HRMS spectra of BA-G are available in Figures S3-S5.

\subsection{Preparation of BNPs and GOx@BNPs}

BNPs were constructed through self-assembly of WP6 and BA-G. Typically, BA-G was dissolved in $300 \mu \mathrm{L}$ of DMSO/MDF solution $(v / v=2: 1)$ to obtain a stock solution $\left(1 \times 10^{-2} \mathrm{M}\right)$. Then, $45 \mu \mathrm{L}$ of BA-G stock solution was rapidly injected into WP6 aqueous solution with a 5:1 ratio of BA-G and WP6 to obtain $3 \mathrm{~mL}$ solutions. The mixtures were shaken slowly for 5 minutes and then left to stand overnight to form stable supramolecular BNP nanoparticles.

GOx-loaded nanoparticles were constructed based on BNPs. Briefly, $300 \mu \mathrm{L}$ of $2000 \mu \mathrm{g} / \mathrm{mL}$ GOx solution were added to the aqueous solution containing WP6. Subsequently, $45 \mu \mathrm{L}$ of DMSO/DMF stock solution $(v / v=2: 1)$ was added to BA-G to obtain $3 \mathrm{~mL}$ ultimate solutions (the ultimate concentration of BA-G was $1 \times 10^{-4} \mathrm{M}$, and the ultimate concentration of GOx was $200 \mu \mathrm{g} / \mathrm{mL}$ ). The mixtures were shaken for 5 minutes and then left to stand overnight. To remove organic solvents and unloaded GOx, the mixtures were further purified via dialysis (molecular weight cutoff 300000). The GOx-loaded nanoparticles were successfully prepared and denoted as GOx@BNPs.

Furthermore, we also prepared FITC-GOx-loaded nanoparticles according to similar procedures, and used fluorescence spectroscopy to quantify the GOx loading capability.

The GOx loading content (wt \%) and loading efficiency (\%) were calculated by the following equation:

Loading content $($ wt $\%)=\left(m_{G O x \text {-loaded }} / m_{G O x \text {-loaded }}+m_{W P 6}+m_{B A-G}\right) \times 100$

Encapsulation efficiency $(\%)=\left(m_{G O x \text {-loaded }} / m_{G O x}\right) \times 100$

where $m_{G O x \text {-loaded }}, m_{G O x}, m_{W P 6}$, and $m_{B A-G}$ are the mass of GOx encapsulated into the vesicles and the mass of GOx, WP6, and BA-G added, respectively. The mass of GOx was measured via fluorescence spectroscopy at $520 \mathrm{~nm}$ and calculated according to a standard calibration curve of GOx in deionized water, with concentrations from 10 to $100 \mu \mathrm{g} / \mathrm{mL}$.

\subsection{Synthesis of FITC-GOx}

FITC-GOx was prepared as described in [50]. Briefly, FITC solution $(10 \mathrm{mg} / \mathrm{mL}$ in anhydrous DMSO, $25 \mu \mathrm{L}$ ) was added to $1 \mathrm{~mL}$ aqueous GOx solutions $(10 \mathrm{mg} / \mathrm{mL}$ containing $100 \mathrm{mM}$ sodium carbonate). The reaction was further incubated at $4{ }^{\circ} \mathrm{C}$ overnight, followed by dialysis with deionized water overnight in the dark and, finally, lyophilization.

\subsection{In Vitro Release of $B A$}

Briefly, BNP solution was treated with varying concentrations of GSH $(0$ or $5 \mu \mathrm{M}$, or $10 \mathrm{mM})$ or $\mathrm{H}_{2} \mathrm{O}_{2}(0,50$, or $100 \mu \mathrm{M})$ at $37^{\circ} \mathrm{C}$. Twenty microliters of the mixture solution $\left(0.5 \times 10^{-4} \mathrm{M}\right)$ was further taken for HPLC measurement at different timepoints $(0,1,2,4$, $6,8,12,24$, and $48 \mathrm{~h}$ ). The released BA was detected via HPLC (SHIMADZU, Kyoto, Japan) using $90 \%$ methanol and $10 \%$ water containing $0.1 \%$ phosphoric acid as a mobile phase, with a flow rate of $1 \mathrm{~mL} \mathrm{~min}^{-1}$ (Agilent XDB C18 reversed-phase $(150 \mathrm{~mm} \times 4.6 \mathrm{~mm}$, $5 \mu \mathrm{m})$; temperature, $25^{\circ} \mathrm{C}$; UV detector at $210 \mathrm{~nm}$ ).

\section{6. $p H$ Variation under Different Concentrations of Glucose}

Different amounts of glucose $(0,0.5$, or $1 \mathrm{mg} / \mathrm{mL})$ were added to GOx@BNPs $\left(1 \times 10^{-4} \mathrm{M}\right.$, in which the GOx concentration was $40.2 \mu \mathrm{g} / \mathrm{mL})$ aqueous solution $(\mathrm{pH}=7.0)$, and the $\mathrm{pH}$ values were monitored using a $\mathrm{pH}$ meter at different timepoints. Furthermore, the GOx $(40.2 \mu \mathrm{g} / \mathrm{mL})$ and BNPs $\left(1 \times 10^{-4} \mathrm{M}\right)$ with no glucose were set as control groups. 


\subsection{Measurement of $\cdot \mathrm{OH}$ Generation}

3,3',5,5'-Tetramethylbenzidine (TMB) was used to investigate the generation of $\cdot \mathrm{OH}$ through UV-Vis spectra. With TMB oxidized by $\cdot \mathrm{OH}$, the change in absorbance intensity at $665 \mathrm{~nm}$ in solutions treated with different formulations was monitored at $37^{\circ} \mathrm{C}$. In addition, the $\cdot \mathrm{OH}$ generation was also monitored via electron paramagnetic resonance (EPR) (Bruker, Karlsruhe, German) with the $\cdot \mathrm{OH}$-trapping probe 5, 5-dimethyl-1-pyrroline N-oxide (DMPO) (Sigma-Aldrich, St. Louis, MO, USA).

Firstly, the time-dependent $\cdot \mathrm{OH}$ generation was investigated: $25 \mu \mathrm{L}$ of TMB $(10.6 \mathrm{mg} / \mathrm{mL})$ in DMSO and $50 \mu \mathrm{L}$ of aqueous glucose solution $(24 \mathrm{mg} / \mathrm{mL})$ were added to a $1 \mathrm{~mL}$ GOx@BNPs solution to obtain a mixed suspension (BA-G $100 \mu \mathrm{M}, \mathrm{TMB} 1 \mathrm{mM}, \mathrm{GOx} 40.2 \mu \mathrm{g} / \mathrm{mL}$, glucose $1 \mathrm{mg} / \mathrm{mL}$ ), and the $\cdot \mathrm{OH}$-induced TMB oxidation was monitored at different timepoints.

Secondly, the glucose-dependent $\cdot \mathrm{OH}$ generation was further investigated: $25 \mu \mathrm{L}$ of TMB $(10.6 \mathrm{mg} / \mathrm{mL})$ in DMSO and aqueous glucose solutions of various concentrations $(0,10,20,30,40$, or $50 \mu \mathrm{L} ; 20 \mathrm{mg} / \mathrm{mL})$ were added to $1 \mathrm{~mL}$ GOx@BNPs solutions to obtain a mixed suspension (with the same BA-G concentration of $100 \mu \mathrm{M}$, the same TMB concentration of $1 \mathrm{mM}$, and the same GOx concentration of $40.2 \mu \mathrm{g} / \mathrm{mL}$ ), and the $\cdot \mathrm{OH}-$ induced TMB oxidation was tested by recording the change in the absorbance value at $665 \mathrm{~nm}$ via UV-Vis spectroscopy at $37^{\circ} \mathrm{C}$ for $4 \mathrm{~h}$.

Finally, the EPR results further proved the robust ability of $\cdot \mathrm{OH}$ generation. Briefly, $100 \mu \mathrm{L}$ of the prepared glucose solution $(10 \mathrm{mg} / \mathrm{mL})$ was added to $1 \mathrm{~mL}$ of $\mathrm{GOx}(40.2 \mu \mathrm{g} / \mathrm{mL})$, BNPs $(100 \mu \mathrm{M})$, or GOx@BNPs (with the same BA-G concentration of $100 \mu \mathrm{M}$ and the same GOx concentration of $40.2 \mu \mathrm{g} / \mathrm{mL}$ ). After incubation at $37^{\circ} \mathrm{C}$ for 4 hours, DMPO was added, and the $\cdot \mathrm{OH}$ generation was monitored via EPR.

\subsection{In Vitro Cytotoxicity by Intracellular Drug Delivery}

The in vitro cytotoxicity of GOx@BNPs against MCF-7 human breast cancer cells and A549 human lung cancer cells were evaluated by MTT assay. Briefly, the cancer cells were seeded in 96-well plates at a density of $1 \times 10^{4}$ cells per well in $100 \mu \mathrm{L}$ of DMEM containing $10 \%$ fetal bovine serum (Gibco), and cultured in $5 \% \mathrm{CO}_{2}$ at $37^{\circ} \mathrm{C}$ for $24 \mathrm{~h}$. Then, cultured cells were washed twice with PBS, and incubated with glucose/serum-free media for $2 \mathrm{~h}$. Next, $100 \mu \mathrm{L}$ of fresh glucose/serum-free media containing different concentrations of BA, BNPs, GOx, or GOx@BNPs were used to treat cells for $4 \mathrm{~h}$. Undelivered sample was gently washed out at once with PBS, and the cells were further incubated with glucose/serumfree media for $30 \mathrm{~min}$. Then, the cells were incubated with glucose-containing media for $24 \mathrm{~h}$. Subsequently, $10 \mu \mathrm{L}$ of MTT solution $(5 \mathrm{mg} / \mathrm{mL})$ was added into each well and incubated for another $4 \mathrm{~h}$. After that, the media containing MTT were removed, and dimethyl sulfoxide (DMSO, $100 \mu \mathrm{L}$ ) was added to each well to dissolve the MTT formazan crystals. Finally, the plates were shaken for $30 \mathrm{~min}$, and the absorbance of the formazan product was measured at $490 \mathrm{~nm}$ using a microplate reader (Thermo Scientific, Waltham, MA, USA). Untreated cells in media were used as blank controls. All experiments were carried out with five replicates. The cytotoxicity was expressed as the percentage of cell viability relative to the blank control.

\subsection{Live/Dead Cell Staining}

The live/dead cell staining experiment was carried out via CLSM. After being cultured for $24 \mathrm{~h}$ in 96-well plates, A549 cells were incubated with PBS and GOx@BNPs (with the same BA concentration of $10 \mu \mathrm{M}$ ) for $12 \mathrm{~h}$ via intracellular drug delivery. The A549 viability was tested after cell death with $2 \mu \mathrm{M}$ calcein AM and $4 \mu \mathrm{M}$ PI for 30 min via CLSM (green channel: $\lambda \mathrm{ex}=488 \mathrm{~nm}, \lambda \mathrm{em}=500-530 \mathrm{~nm}$; red channel: $\lambda \mathrm{ex}=535 \mathrm{~nm}, \lambda \mathrm{em}=600-630 \mathrm{~nm}$ ).

\subsection{Cellular Uptake and Subcellular Distribution}

The cellular uptake and subcellular distribution of FITC-GOx-loaded vesicles (FITCGOx@NPs) were examined in A549 cancer cells. Briefly, A549 cells were seeded in a confocal dish at a density of $1 \times 10^{5}$ cells and cultured in $1.0 \mathrm{~mL}$ of complete RPMI-1640 
culture medium for $24 \mathrm{~h}$ before treatment. Then, the original medium was removed and cells were incubated with glucose/serum-free medium for $2 \mathrm{~h}$. Next, cells were treated with FITC-GOx@NPs $(10 \mu \mathrm{M})$ for $1 \mathrm{~h}$ or $2 \mathrm{~h}$. Then, the culture medium was removed and cells were washed thrice with PBS. Thereafter, the LysoTracker Red DND-99 (Thermo Fisher, Waltham, MA, USA) was added to the medium at a final concentration of $75 \mathrm{nM}$ for $1 \mathrm{~h}$ to label lysosomes. Next, the cells were washed with PBS three times, and Hoechst 33342 (Thermo Fisher, Waltham, MA, USA) was added to the medium at a final concentration of $1 \mu \mathrm{g} / \mathrm{mL}$ for $15 \mathrm{~min}$ to stain nuclei. Finally, the culture medium was removed, and the cells were washed thrice with PBS, after which the cells were fixed in $4 \%$ paraformaldehyde for $20 \mathrm{~min}$ and washed three times with PBS. Fluorescence microscopy (Leica TCS SP8, Weztlar, German) was used to investigate the cellular uptake and intracellular localization. The fluorescence characteristics of FITC-GOx-loaded vesicles were used to directly monitor the localization of GOx without utilizing additional dye.

\subsection{Intracellular Reactive Oxygen Species (ROS) Detection}

The intracellular generation of ROS was determined using the ROS probe $2^{\prime}, 7^{\prime}$ dichlorodihydrofluorescein diacetate (DCFH-DA). The A549 cells were seeded at a density of $5 \times 10^{5}$ cells in a confocal dish and incubated with $1 \mathrm{~mL}$ of complete RPMI-1640 medium at $37^{\circ} \mathrm{C}$ in $5 \% \mathrm{CO}_{2}$ for $24 \mathrm{~h}$. The medium was replaced with fresh RPMI-1640 containing PBS, GOx $(4.02 \mu \mathrm{g} / \mathrm{mL})$, BA $(10 \mu \mathrm{M})$, or GOx@BNPs $(10 \mu \mathrm{M}$, in which the GOx concentration was $4.02 \mu \mathrm{g} / \mathrm{mL})$. After $2 \mathrm{~h}$, DCFH-DA $(10 \mu \mathrm{M})$ was added and incubated for $30 \mathrm{~min}$. Then, the cells were washed three times with PBS and imaged via CLSM. DCF decomposed from DCFH-DA was excited at $488 \mathrm{~nm}$, and fluorescence was detected from 510 to $550 \mathrm{~nm}$.

\subsection{Intracellular ATP Level Measurements}

The ATP levels in A549 cells were measured using an ATP assay kit (Nanjing Jiancheng Bioengineering Institute, Nanjing, China). Briefly, A549 cells were seeded in a six-well plate at a density of 80,000 cells per well and cultured for $24 \mathrm{~h}$. The cells were incubated with PBS, GOx $(4.02 \mu \mathrm{g} / \mathrm{mL}), B A(10 \mu \mathrm{M})$, or GOx@BNPs $(10 \mu \mathrm{M}$, in which the GOx concentration was $4.02 \mu \mathrm{g} / \mathrm{mL}$ ) for $6 \mathrm{~h}$. Next, the recommended procedures of the kit were used to determine the ATP levels in cells.

\subsection{Evaluation of Mitochondrial Transmembrane Potential (MTP)}

A549 cells were seeded in 6-well cell culture plates (Corning Incorporated, New York, NY, USA) at a density of $5 \times 10^{4}$ cells per well in $1 \mathrm{~mL}$ of $90 \% \mathrm{~F} 12 \mathrm{~K}$ and $10 \%$ FBS medium, and cultured at $37{ }^{\circ} \mathrm{C}$ in $5 \% \mathrm{CO}_{2}$ for $24 \mathrm{~h}$. Then, the original medium was removed, and the cells were incubated with glucose-free 1640 medium. PBS, GOx $(4.02 \mu \mathrm{g} / \mathrm{mL}), \mathrm{BA}(10 \mu \mathrm{M})$, and GOx@BNPs $(10 \mu \mathrm{M}$, in which the GOx concentration was $4.02 \mu \mathrm{g} / \mathrm{mL}$ ) were dissolved in glucose/serum-free media at $37^{\circ} \mathrm{C}$ for $24 \mathrm{~h}$. A549 cells incubated with PBS were used as controls. After incubation for $24 \mathrm{~h}$, the cell solutions were trypsinized and centrifuged at $2000 \mathrm{rpm}$ for $5 \mathrm{~min}$. The culture medium was removed, and the cells were washed twice with cold PBS. After removal of the supernatants, the cells were resuspended in incubation buffer $(500 \mu \mathrm{L})$ and then incubated with a mitochondrial transmembrane potential (MTP) detection kit (Jiangsu KeyGEN Biotech Corp., Ltd, Nanjing, China) according to the manufacturer's protocol: JC- 1 was added to the cell suspensions, and after incubation in the dark for $15 \mathrm{~min}$, the percentage of green fluorescence cells was detected via flow cytometry using a Becton Dickinson FACSCalibur flow cytometer. The decrease in MTP was indicated by an increase in the percentage of green fluorescence cells.

\subsection{Flow Cytometric Analysis of Apoptosis}

A549 cells were seeded in 6-well cell culture plates (Corning Incorporated, New York, NY, USA) at a density of $5 \times 10^{4}$ cells per well in $1 \mathrm{~mL}$ of complete RPMI 1640 medium, and cultured at $37^{\circ} \mathrm{C}$ in $5 \% \mathrm{CO}_{2}$ for $24 \mathrm{~h}$. Then, the original medium was removed, and cells were incubated with glucose-free 1640 medium. PBS, GOx $(4.02 \mu \mathrm{g} / \mathrm{mL})$, BA $(10 \mu \mathrm{M})$, 
and GOx@BNPs (10 $\mu \mathrm{M}$, in which the GOx concentration was $4.02 \mu \mathrm{g} / \mathrm{mL})$ were dissolved in glucose/serum-free media at $37^{\circ} \mathrm{C}$ for $24 \mathrm{~h}$. A549 cells incubated with PBS were used as controls. After incubation for $24 \mathrm{~h}$, the cell solutions were trypsinized and centrifuged at $2000 \mathrm{rpm}$ for $5 \mathrm{~min}$. The culture medium was removed and the cells were washed twice with cold PBS. After removal of the supernatants, the cells were resuspended in binding buffer $(500 \mu \mathrm{L})$. The apoptotic cells were determined by staining using an Annexin V-FITC/PI apoptosis detection kit (Jiangsu KeyGEN Biotech Corp., Ltd, Naijing, China) according to the manufacturer's protocol: Annexin V-FITC $(5 \mu \mathrm{L})$ and propidium iodide $(5 \mu \mathrm{L})$ were added to the cell suspensions, and after incubation in the dark for 15 min, cell apoptosis was detected via flow cytometry using a Becton Dickinson FACSCalibur flow cytometer, and $5 \times 10^{5}$ cells were tested for each sample.

\subsection{Statistical Analysis}

The statistical analysis of different groups was compared using Student's $t$-test. $p$-values on graphs are denoted within each figure panel as ${ }^{*} p<0.05$ or ${ }^{\#} p<0.05$ (significant).

\section{Conclusions}

In summary, GSH/ROS dual-responsive novel supramolecular nanoparticles (GOx@BNPs) for chemo-chemodynamic combination therapy were developed based on water-soluble pillar[6]arene and a thioether-bridged ferrocene-modified natural anticancer BA prodrug, followed by encapsulation of GOx in the nanoparticles. The encapsulation of GOx in the nanoparticles could first catalyze the conversion of glucose into gluconic acid and $\mathrm{H}_{2} \mathrm{O}_{2}$, and then the generation of $\mathrm{H}_{2} \mathrm{O}_{2}$ further reacted with ferrocene to produce highly active $\cdot \mathrm{OH}$ in succession via the Fenton reaction. The novel supramolecular nanoparticles could be activated by the overexpressed GSH and ROS in the TME, which not only improved the BA recovery and release capability of GOx@BNPs, but also enhanced the Fenton reaction to produce $\cdot \mathrm{OH}$ and exert potent cytotoxicity in cancer cells. Investigation of antitumor activity and mechanisms revealed that the dramatic suppression of A549 cancer cell growth induced by GOx@BNPs was derived from the elevation of ROS levels, the decrease in ATP and MTP and, finally, the induction of cell apoptosis through the synergistic interaction of CDT, starvation therapy, and chemotherapy via an intratumoral cascade reaction. This work presents a novel method to regulate the tumor microenvironment for improved CDT and the preparation of novel GSH/ROS dual-responsive supramolecular nanoparticles based on pillar[6]arene and a BA prodrug for the combination of CDT, starvation therapy, and chemotherapy, which may become a promising strategy for cancer treatment, and warrants intensive study.

Supplementary Materials: The following are available online: Figure S1: ${ }^{1} \mathrm{HNMR}$ spectra of compound 3; Figure S2: ${ }^{1} \mathrm{HNMR}$ spectra of compound 9; Figure S3: ${ }^{1} \mathrm{HNMR}$ spectra of BA-G; Figure S4: ${ }^{13}$ CNMR spectra of BA-G; Figure S5: HRMS of BA-G; Figure S6: Zeta potential of BNPs; Figure S7: Stability of the BNPs and GOx@BNPs.

Author Contributions: Conceptualization, P.Z., W.Z., X.L. and Y.L.; methodology, P.Z., W.L., J.Q. and Y.L.; investigation, P.Z., W.L., J.Q., C.M., W.S. and Z.X.; resources, W.Z. and Y.L.; writing-original draft preparation, P.Z.; writing-review and editing, P.Z., W.Z., X.L. and Y.L.; visualization, Y.L.; supervision, W.Z. and Y.L.; project administration, Y.L. All authors have read and agreed to the published version of the manuscript.

Funding: This research was funded by the Key Natural Science Foundation of Jiangsu Higher Education Institutions (20KJA350002), the China Postdoctoral Science Foundation (2018T110533 and 2016M590488), the project of "Jiangsu 333 High-Level Talents", the project of "Jiangsu Six Peaks of Talent" (2016-SWYY-CXTD-008 and 2014-SWYY-044), and Applied Research Projects of Nantong City (MS12020047 and MS12018079).

Institutional Review Board Statement: Not applicable.

Informed Consent Statement: Not applicable. 


\section{Data Availability Statement: Not applicable.}

Conflicts of Interest: The authors declare that there is no conflict of interest regarding the publication of this article.

\section{References}

1. Siegel, R.L.; Miller, K.D.; Jemal, A. Cancer statistics, 2018. CA Cancer J. Clin. 2018, 68, 7-30. [CrossRef]

2. Bray, F.; Ferlay, J.; Soerjomataram, I.; Siegel, R.L.; Torre, L.A.; Jemal, A. Global cancer statistics 2018: GLOBOCAN estimates of incidence and mortality worldwide for 36 cancers in 185 countries. CA Cancer J. Clin. 2018, 68, 394-424. [CrossRef]

3. D'Arcy, M.S. A review of the chemopreventative and chemotherapeutic properties of the phytochemicals berberine, resveratrol and curcumin, and their influence on cell death via the pathways of apoptosis and autophagy. Cell Biol. Int. 2020, 44, 1781-1791. [CrossRef]

4. Butler, M.S.; Robertson, A.A.; Cooper, M.A. Natural product and natural product derived drugs in clinical trials. Nat. Prod. Rep. 2014, 31, 1612-1661. [CrossRef]

5. Newman, D.J.; Cragg, G.M. Natural Products as Sources of New Drugs from 1981 to 2014. J. Nat. Prod. 2016, $79,629-661$. [CrossRef]

6. Li, X.; Liu, X.; Deng, R.; Gao, S.; Jiang, Q.; Liu, R.; Li, H.; Miao, Y.; Zhai, Y.; Zhang, S.; et al. Betulinic acid attenuated bleomycin-induced pulmonary fibrosis by effectively intervening Wnt/beta-catenin signaling. Phytomedicine 2021, 81, 153428. [CrossRef]

7. Zhang, X.; Hu, J.; Chen, Y. Betulinic acid and the pharmacological effects of tumor suppression. Mol. Med. Rep. 2016, 14, 4489-4495. [CrossRef] [PubMed]

8. Zhang, D.M.; Xu, H.G.; Wang, L.; Li, Y.J.; Sun, P.H.; Wu, X.M.; Wang, G.J.; Chen, W.M.; Ye, W.C. Betulinic Acid and its Derivatives as Potential Antitumor Agents. Med. Res. Rev. 2015, 35, 1127-1155. [CrossRef] [PubMed]

9. Hoenke, S.; Heise, N.V.; Kahnt, M.; Deigner, H.P.; Csuk, R. Betulinic acid derived amides are highly cytotoxic, apoptotic and selective. Eur. J. Med. Chem. 2020, 207, 112815. [CrossRef] [PubMed]

10. Augustine, R.; Kalva, N.; Kim, H.A.; Zhang, Y.; Kim, I. pH-Responsive Polypeptide-Based Smart Nano-Carriers for Theranostic Applications. Molecules 2019, 24, 2961. [CrossRef]

11. Shen, M.; Hu, Y.; Yang, Y.; Wang, L.; Yang, X.; Wang, B.; Huang, M. Betulinic Acid Induces ROS-Dependent Apoptosis and S-Phase Arrest by Inhibiting the NF-kappaB Pathway in Human Multiple Myeloma. Oxid. Med. Cell Longev. 2019, $2019,5083158$. [CrossRef]

12. Phillips, J.; Phillips, I.; Enya, B.; Zhao, H.; Nitta, T. Effect of betulinic acid and its ionic derivatives on M-MuLV replication. Biochem. Biophys. Res. Commun. 2018, 500, 365-369. [CrossRef] [PubMed]

13. Kumar, P.; Gautam, A.K.; Kumar, U.; Bhadauria, A.S.; Singh, A.K.; Kumar, D.; Mahata, T.; Maity, B.; Bera, H.; Saha, S. Mechanistic exploration of the activities of poly (lactic-co-glycolic acid)-loaded nanoparticles of betulinic acid against hepatocellular carcinoma at cellular and molecular levels. Arch. Physiol. Biochem. 2020, 6, 1-13. [CrossRef] [PubMed]

14. Halder, A.; Jethwa, M.; Mukherjee, P.; Ghosh, S.; Das, S.; Helal Uddin, A.B.M.; Mukherjee, A.; Chatterji, U.; Roy, P. Lactoferrintethered betulinic acid nanoparticles promote rapid delivery and cell death in triple negative breast and laryngeal cancer cells. Artif. Cells Nanomed. Biotechnol. 2020, 48, 1362-1371. [CrossRef] [PubMed]

15. Li, S.; Zhang, J.; Fang, Y.; Yi, J.; Lu, Z.; Chen, Y.; Guo, B. Enhancing Betulinic Acid Dissolution Rate and Improving Antitumor Activity via Nanosuspension Constructed by Anti-Solvent Technique. Drug Des. Dev. Ther. 2020, 14, 243-256. [CrossRef] [PubMed]

16. Zhang, C.; Bu, W.; Ni, D.; Zhang, S.; Li, Q.; Yao, Z.; Zhang, J.; Yao, H.; Wang, Z.; Shi, J. Synthesis of Iron Nanometallic Glasses and Their Application in Cancer Therapy by a Localized Fenton Reaction. Angew. Chem. Int. Ed. Engl. 2016, 55, 2101-2106. [CrossRef]

17. Tang, Z.; Liu, Y.; He, M.; Bu, W. Chemodynamic Therapy: Tumour Microenvironment-Mediated Fenton and Fenton-like Reactions. Angew. Chem. Int. Ed. Engl. 2019, 58, 946-956. [CrossRef]

18. Tang, Z.; Zhao, P.; Wang, H.; Liu, Y.; Bu, W. Biomedicine Meets Fenton Chemistry. Chem. Rev. 2021, 121, 1981-2019. [CrossRef]

19. de la Cruz-Lopez, K.G.; Castro-Munoz, L.J.; Reyes-Hernandez, D.O.; Garcia-Carranca, A.; Manzo-Merino, J. Lactate in the Regulation of Tumor Microenvironment and Therapeutic Approaches. Front Oncol. 2019, 9, 1143. [CrossRef]

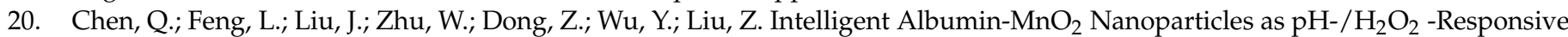
Dissociable Nanocarriers to Modulate Tumor Hypoxia for Effective Combination Therapy. Adv. Mater. 2016, 28, 7129-7136. [CrossRef]

21. Ranji-Burachaloo, H.; Karimi, F.; Xie, K.; Fu, Q.; Gurr, P.A.; Dunstan, D.E.; Qiao, G.G. MOF-Mediated Destruction of Cancer Using the Cell's Own Hydrogen Peroxide. ACS Appl. Mater. Inter. 2017, 9, 33599-33608. [CrossRef]

22. Li, J.; Ke, W.; Wang, L.; Huang, M.; Yin, W.; Zhang, P.; Chen, Q.; Ge, Z. Self-sufficing $\mathrm{H}_{2} \mathrm{O}_{2}$-responsive nanocarriers through tumor-specific $\mathrm{H}_{2} \mathrm{O}_{2}$ production for synergistic oxidation-chemotherapy. J. Control. Release 2016, 225, 64-74. [CrossRef]

23. He, T.; Xu, H.; Zhang, Y.; Yi, S.; Cui, R.; Xing, S.; Wei, C.; Lin, J.; Huang, P. Glucose Oxidase-Instructed Traceable SelfOxygenation/Hyperthermia Dually Enhanced Cancer Starvation Therapy. Theranostics 2020, 10, 1544-1554. [CrossRef] [PubMed]

24. Fu, L.H.; Qi, C.; Lin, J.; Huang, P. Catalytic chemistry of glucose oxidase in cancer diagnosis and treatment. Chem. Soc. Rev. 2018, 47, 6454-6472. [CrossRef] [PubMed] 
25. Martinez-Outschoorn, U.E.; Peiris-Pages, M.; Pestell, R.G.; Sotgia, F.; Lisanti, M.P. Cancer metabolism: A therapeutic perspective. Nat. Rev. Clin. Oncol. 2017, 14, 113. [CrossRef] [PubMed]

26. Counihan, J.L.; Grossman, E.A.; Nomura, D.K. Cancer Metabolism: Current Understanding and Therapies. Chem. Rev. 2018, 118, 6893-6923. [CrossRef]

27. Tang, Y.; Ji, Y.; Yi, C.; Cheng, D.; Wang, B.; Fu, Y.; Xu, Y.; Qian, X.; Choonara, Y.E.; Pillay, V.; et al. Self-accelerating $\mathrm{H}_{2} \mathrm{O}_{2}$-responsive Plasmonic Nanovesicles for Synergistic Chemo/starving therapy of Tumors. Theranostics 2020, 10, 8691-8704. [CrossRef]

28. Song, N.; Lou, X.Y.; Ma, L.; Gao, H.; Yang, Y.W. Supramolecular nanotheranostics based on pillarenes. Theranostics 2019, 9 , 3075-3093. [CrossRef]

29. Webber, M.J.; Langer, R. Drug delivery by supramolecular design. Chem. Soc. Rev. 2017, 46, 6600-6620. [CrossRef]

30. Feng, H.T.; Li, Y.; Duan, X.; Wang, X.; Qi, C.; Lam, J.W.Y.; Ding, D.; Tang, B.Z. Substitution Activated Precise Phototheranostics through Supramolecular Assembly of AIEgen and Calixarene. J. Am. Chem. Soc. 2020, 142, 15966-15974. [CrossRef]

31. Zhang, R.; Wang, C.; Long, R.; Chen, T.; Yan, C.; Yao, Y. Pillar[5]arene Based [1]rotaxane Systems With Redox-Responsive Host-Guest Property: Design, Synthesis and the Key Role of Chain Length. Front. Chem. 2019, 7, 508. [CrossRef]

32. Yu, G.; Jie, K.; Huang, F. Supramolecular Amphiphiles Based on Host-Guest Molecular Recognition Motifs. Chem. Rev. 2015, 115, 7240-7303. [CrossRef] [PubMed]

33. Wu, X.; Gao, L.; Hu, X.Y.; Wang, L. Supramolecular Drug Delivery Systems Based on Water-Soluble Pillar[n]arenes. Chem. Rec. 2016, 16, 1216-1227. [CrossRef] [PubMed]

34. Li, Y.F.; Li, Z.; Lin, Q.; Yang, Y.W. Functional supramolecular gels based on pillar[n]arene macrocycles. Nanoscale 2020, 12, 2180-2200. [CrossRef] [PubMed]

35. Li, B.; Meng, Z.; Li, Q.; Huang, X.; Kang, Z.; Dong, H.; Chen, J.; Sun, J.; Dong, Y.; Li, J.; et al. A pH responsive complexation-based drug delivery system for oxaliplatin. Chem. Sci. 2017, 8, 4458-4464. [CrossRef] [PubMed]

36. Qi, Z.; Achazi, K.; Haag, R.; Dong, S.; Schalley, C.A. Supramolecular hydrophobic guest transport system based on pillar [5] arene. Chem. Commun. 2015, 51, 10326-10329. [CrossRef]

37. Kakuta, T.; Yamagishi, T.A.; Ogoshi, T. Stimuli-Responsive Supramolecular Assemblies Constructed from Pillar[n]arenes. Acc. Chem. Res. 2018, 51, 1656-1666. [CrossRef]

38. Shao, L.; Zhou, J.; Hua, B.; Yu, G. A dual-responsive supra-amphiphile based on a water-soluble pillar[7]arene and a naphthalene diimide-containing guest. Chem. Commun (Camb) 2015, 51, 7215-7218. [CrossRef]

39. Zuo, M.; Qian, W.; Xu, Z.; Shao, W.; Hu, X.Y.; Zhang, D.; Jiang, J.; Sun, X.; Wang, L. Multiresponsive Supramolecular Theranostic Nanoplatform Based on Pillar [5] arene and Diphenylboronic Acid Derivatives for Integrated Glucose Sensing and Insulin Delivery. Small 2018, 14, e1801942. [CrossRef]

40. Lv, X.; Xia, D.; Zuo, Y.; Wu, X.; Wei, X.; Wang, P. Gemini-Type Supramolecular Amphiphile Based on a Water-Soluble Pillar [5] arene and an Azastilbene Guest and Its Application in Stimuli-Responsive Self-Assemblies. Langmuir 2019, 35, 8383-8388. [CrossRef]

41. Luo, C.; Sun, J.; Liu, D.; Sun, B.; Miao, L.; Musetti, S.; Li, J.; Han, X.; Du, Y.; Li, L.; et al. Self-Assembled Redox Dual-Responsive Prodrug-Nanosystem Formed by Single Thioether-Bridged Paclitaxel-Fatty Acid Conjugate for Cancer Chemotherapy. Nano. Lett. 2016, 16, 5401-5408. [CrossRef] [PubMed]

42. Yu, G.; Xue, M.; Zhang, Z.; Li, J.; Han, C.; Huang, F. A water-soluble pillar [6] arene: Synthesis, host-guest chemistry, and its application in dispersion of multiwalled carbon nanotubes in water. J. Am. Chem. Soc. 2012, 134, 13248-13251. [CrossRef] [PubMed]

43. Durand, N.; Storz, P. Targeting reactive oxygen species in development and progression of pancreatic cancer. Expert Rev. Anticanc. Ther. 2017, 17, 19-31. [CrossRef] [PubMed]

44. Duan, Q.; Cao, Y.; Li, Y.; Hu, X.; Xiao, T.; Lin, C.; Pan, Y.; Wang, L. pH-Responsive Supramolecular Vesicles Based on Water-Soluble Pillar[6]arene and Ferrocene Derivative for Drug Delivery. J. Am. Chem. Soc. 2013, 135, 10542-10549. [CrossRef]

45. Lu, Y.; Zhang, R.; Liu, S.; Zhao, Y.; Gao, J.; Zhu, L. ZT-25, a new vacuolar H(+)-ATPase inhibitor, induces apoptosis and protective autophagy through ROS generation in HepG2 cells. Eur. J. Pharmacol. 2016, 771, 130-138. [CrossRef]

46. Wang, Y.; Liu, X.; Liu, G.; Wang, X.; Hu, R.; Liang, X. PIG11 over-expression predicts good prognosis and induces HepG2 cell apoptosis via reactive oxygen species-dependent mitochondrial pathway. Biomed. Pharmacother. 2018, 108, 435-442. [CrossRef]

47. Xin, J.; Deng, C.; Aras, O.; Zhou, M.; Wu, C.; An, F. Chemodynamic nanomaterials for cancer theranostics. J. Nanobiotechnol. 2021, 19, 192. [CrossRef]

48. Xia, M.; Yang, M.; Wang, Y.; Tian, F.; Hu, J.; Yang, W.; Tao, S.; Lu, L.; Ding, X.; Jiang, S.; et al. dl-Mandelic acid exhibits high sperm-immobilizing activity and low vaginal irritation: A potential non-surfactant spermicide for contraception. Biomed. Pharmacother. 2020, 126, 110104. [CrossRef]

49. Kumar, P.; Bhadauria, A.S.; Singh, A.K.; Saha, S. Betulinic acid as apoptosis activator: Molecular mechanisms, mathematical modeling and chemical modifications. Life Sci. 2018, 209, 24-33. [CrossRef]

50. Li, J.; Dirisala, A.; Ge, Z.; Wang, Y.; Yin, W.; Ke, W.; Toh, K.; Xie, J.; Matsumoto, Y.; Anraku, Y.; et al. Therapeutic Vesicular Nanoreactors with Tumor-Specific Activation and Self-Destruction for Synergistic Tumor Ablation. Angew. Chem. Int. Ed. Engl. 2017, 56, 14025-14030. [CrossRef] 